Article

\title{
Synthesis and Physicochemical Characterization of the Impurities of Pemetrexed Disodium, an Anticancer Drug
}

\section{Olga Michalak ${ }^{1, *}$, Mariusz M. Gruza ${ }^{1}$, Anna Witkowska ${ }^{1}$, Iwona Bujak ${ }^{1}$ and Piotr Cmoch ${ }^{1,2}$}

1 Pharmaceutical Research Institute, 8 Rydygiera Street, 01-793 Warsaw, Poland;

E-Mails: m.gruza@ifarm.eu (M.M.G.); a.witkowska@ifarm.eu (A.W.); i.bujak@ifarm.eu (I.B.)

2 Institute of Organic Chemistry, Polish Academy of Sciences, 44/52 Kasprzaka Street, 01-224 Warsaw, Poland; E-Mail: piotr.cmoch@icho.edu.pl

* Author to whom correspondence should be addressed; E-Mail: o.michalak@ifarm.eu; Tel.: +48-22-456-3898; Fax: +48-22-456-3838.

Academic Editor: Jean Jacques Vanden Eynde

Received: 30 April 2015 / Accepted: 26 May 2015 / Published: 29 May 2015

\begin{abstract}
A physicochemical characterization of the process-related impurities associated with the synthesis of pemetrexed disodium was performed. The possibility of pemetrexed impurities forming has been mentioned in literature, but no study on their structure has been published yet. This paper describes the development of the synthesis methods for these compounds and discusses their structure elucidation on the basis of two-dimensional NMR experiments and MS data. The identification of these impurities should be useful for the quality control during the production of the pemetrexed disodium salt.
\end{abstract}

Keywords: pemetrexed; impurities; NMR; diastereoisomers

\section{Introduction}

Pemetrexed (1a, Figure 1) is an antifolate antineoplastic agent that exerts its action by disrupting folate-dependent metabolic processes essential for cell replication. It acts by inhibiting three enzymes used in purine and pyrimidine synthesis de novo - thymidylate synthase (TS), dihydrofolate reductase (DHFR), and glycinamide ribonucleotide formyltransferase (GARFT) [1,2]. By inhibiting the formation of precursor purine and pyrimidine nucleotides, pemetrexed prevents the formation of DNA and RNA, which are required for the growth and survival of both normal and cancer cells. 


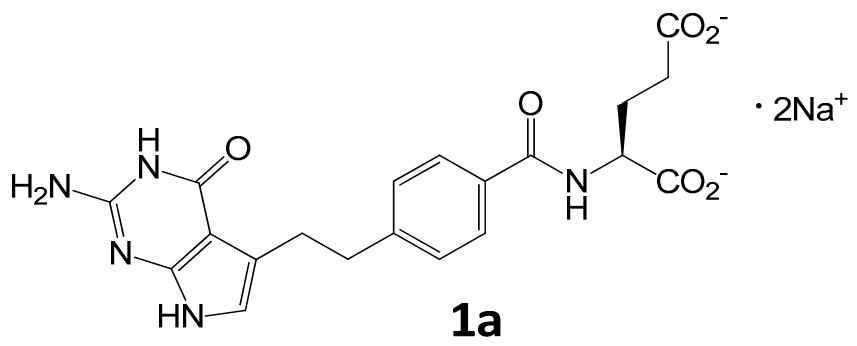

Figure 1. Chemical structures of pemetrexed as the disodium salt 1a.

A pharmaceutical product containing pemetrexed disodium (1a) as the active ingredient is used for the treatment of malignant pleural mesothelioma (MPM) in combination with cisplatin and as a second line agent for the treatment of advanced or metastatic non-small cell lung cancer (NSCLC). Currently, the drug is used as a single agent or in combination with other chemotherapeutic agents for the treatment of other types of cancer, such as breast cancer, bladder cancer, colorectal carcinoma and cervical cancer $[3,4]$.

The product was originally developed by Taylor and co-workers [5] at Princeton University and is available on the market under the brand name ALIMTA $^{\circledR}$ (Lilly). It is a sterile lyophilized powder for intravenous infusion.

The U.S. Food and Drug Administration (FDA) [6] and the European Medicine Agency (EMA) [7] require complete physicochemical characteristic not only for an active pharmaceutical ingredient (API), but also for its key synthetic intermediates. In addition, the determination of a drug substance impurity profile, including known, especially pharmacopeial impurities [8], as well as other unknown impurities, can have a significant impact on the quality and safety of drug products.

The health implications of impurities can be significant because of their potential teratogenic, mutagenic or carcinogenic effects. Therefore, the International Conference on Harmonization (ICH) sets a high standard for the purity of drug substances [9]. If the dose is less than $2 \mathrm{~g} /$ day, impurities over $0.10 \%$ are expected to be identified, qualified and controlled. If the dose exceeds $2 \mathrm{~g} / \mathrm{day}$, the qualification threshold is lowered to $0.05 \%$. It is therefore essential to control and monitor the impurities both in the APIs and the finished drug products. It is also a crucial issue in drug development and manufacturing.

This paper describes a study on identification, synthesis and characterization of the impurities formed during the pemetrexed disodium synthesis. The study will help to understand the formation of the impurities in the pemetrexed disodium synthesis and provide a clue on how to obtain a pure compound.

\section{Results and Discussion}

\subsection{Synthesis of Pemetrexed Disodium}

Convergent synthesis of pemetrexed disodium heptahydrate from key synthetic intermediates (Scheme 1) is well documented and involves firstly the preparation of the $p$-toluenesulfonic acid salt (5a) [10]. The acid 2 is activated for coupling by reaction with 2-chloro-4,6-dimethoxytriazine (CDMT) in presence of $\mathrm{N}$-methylmorpholine (NMM) to form an active ester $\mathbf{3}$ and then reacted with diethyl L-glutamate 4. The product of peptide coupling $\mathbf{5}$ is isolated as $p$-toluenesulfonate $\mathbf{5 a}$ and then 
saponified to produce a free acid form of the drug substance (1). Finally, the $\mathrm{pH}$ is adjusted to $\mathrm{pH} 8$ and the crystalline disodium salt $\mathbf{1 a}$ is isolated as the heptahydrate form $\left(\mathbf{1} \mathbf{a} \cdot \mathbf{7} \mathbf{H}_{2} \mathbf{O}\right)$.

However, we have found a new method for the preparation of pemetrexed disodium 1a in an amorphous form which involves the deprotonation of pemetrexed diacid (1) in the presence of sodium methoxide under anhydrous conditions [11].
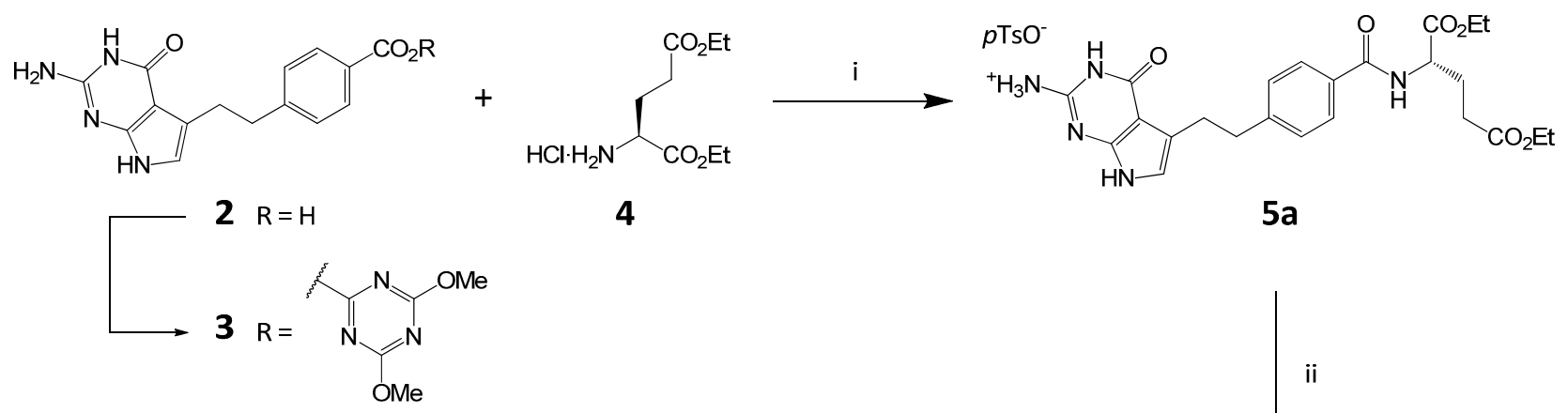

$5 a$
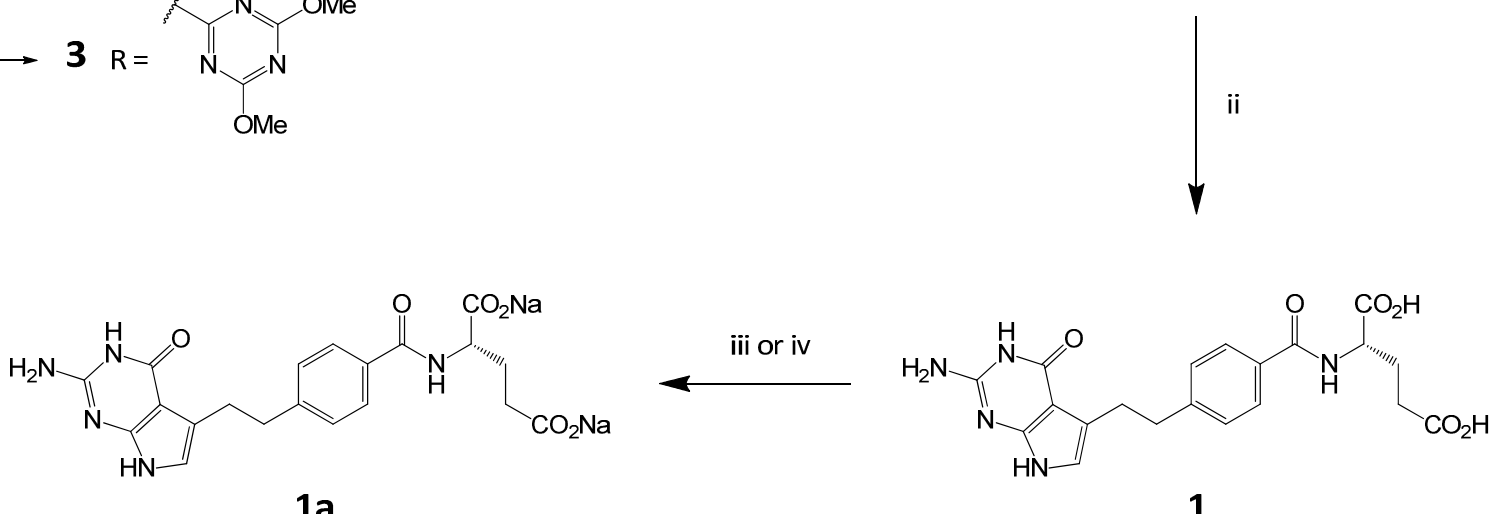

1

Scheme 1. Synthesis of pemetrexed disodium. Conditions: (i) (a) CDMT, NMM, DMF, RT; (b) 4; (c) $p$-TSA; (ii) (a) $\mathrm{NaOH}_{\mathrm{aq}}$, (b) $\mathrm{HCl}_{\mathrm{aq}}$; (iii) to $\mathbf{1 a} \cdot \mathbf{7} \mathbf{H}_{\mathbf{2}} \mathrm{O}$ : (a) $\mathrm{NaOH}_{\mathrm{aq}}$, (b) $\mathrm{HCl}_{\mathrm{aq}}$; (iv) to $\mathbf{1 a}$ (amorphic form): $\mathrm{NaOMe}, \mathrm{MeOH}$.

During the study of process developing we observed that the product, pemetrexed disodium, contained a number of impurities; six of them were identified (Table 1).

At early stage of development process [11] we found that impurity level in some batches of pemetrexed varied in the range from $0.05 \%$ to $0.5 \%$ (HPLC). Further study was undertaken to find out if the measured impurities limits comply with the documentation requirements and if the product may be registered as the API. One of the requirements is to prove that the substance meets the characteristics described in the Pharmacopoeia, i.a., the impurities limits not exceeded specified values.

For routine process controls of batches of the API as well as for development of analytical methods the possession of impurities of appropriate quantity and quality is required. Some impurity standards may be obtained commercially (at a high cost), some of them, mainly those which have not been previously described, are not available commercially. In both cases the elaboration of methods for their synthesis is very advantageous.

\subsection{Structure of Impurities}

The compounds shown in Table 1 were taken into account as potential impurities of the final pemetrexed disodium: 
Table 1. Main impurities of pemetrexed.

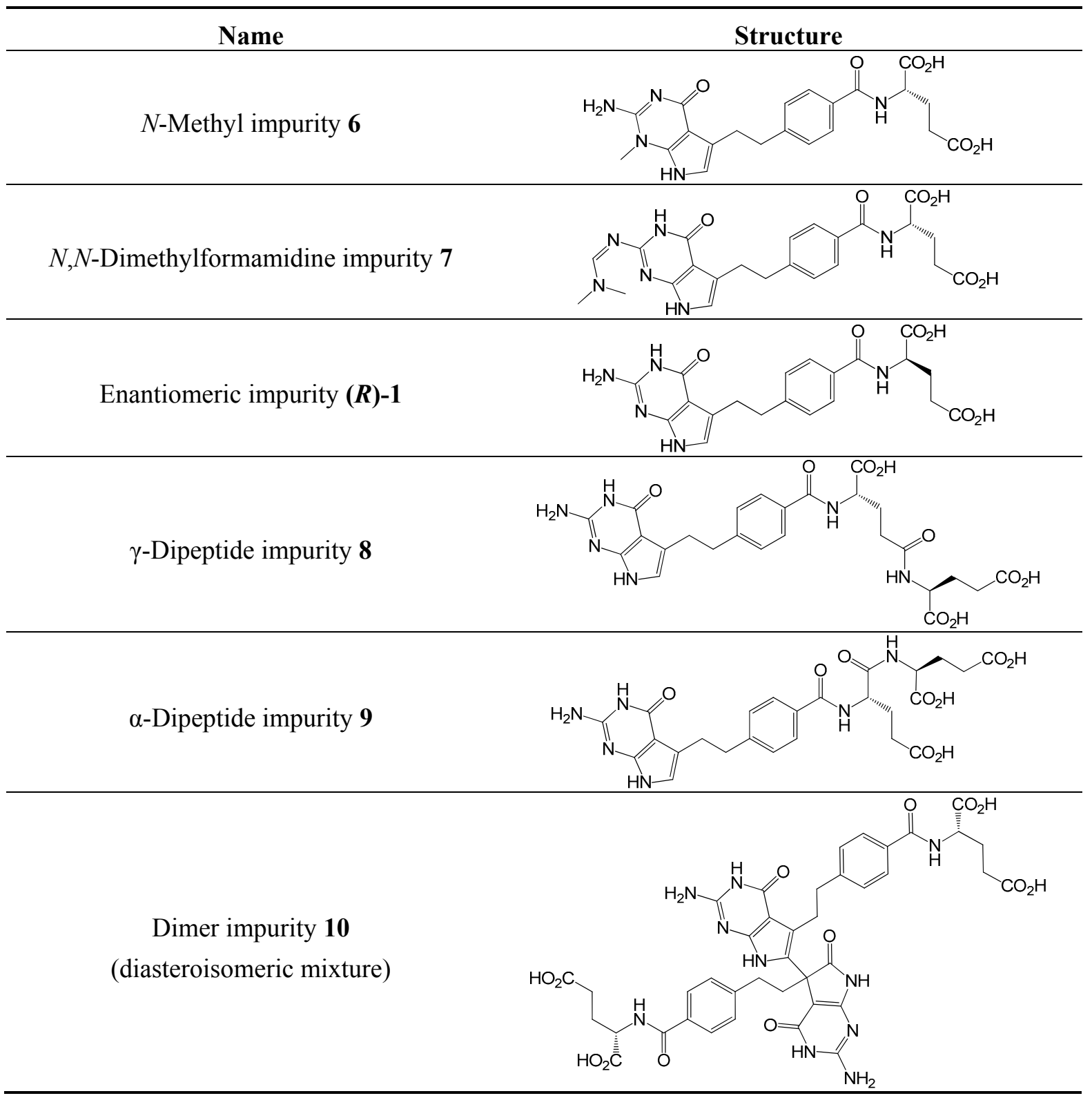

Only the impurities $(\boldsymbol{R})-\mathbf{1}$ (Impurity E), 6 (Impurity A), 8 (Impurity D), 10 (Impurity B and C) have been documented in the European Pharmacopoeia [8]. A detailed synthetic processes and structure confirmation have not been reported for 8, 9, 10. Compounds 6 and 7 were mentioned previously, but without full characterization [12,13]. Detailed HPLC analyses for 6, 8, 10 were also described [14].

The impurities collected in Table 1 were synthesized and fully characterized by different techniques (IR, NMR, MS, HPLC, DSC).

\subsection{Source and Preparation of Impurities}

\subsection{1. $N$-Methyl Impurity 6}

The $N$-methyl impurity $\mathbf{6}$ of pemetrexed is formed while condensing the benzoic acid $\mathbf{2}$ with diethyl L-glutamate 4 in the presence of CMDT and NMM. Kjell and coworkers [12] suggest that the 
decomposition of the excess $\mathrm{CDMT} \cdot \mathrm{NMM}$ complex produces a methylating agent which is capable of methylating the N1-nitrogen of dezazaguanine moiety and giving $\mathbf{6}$ as the final result.

In the first route, derivative $\mathbf{6}$ was generated by alkylation of $\mathbf{1 a}$ with methyl iodide in the presence of triethylamine, followed by the treatment with $1 \mathrm{~N} \mathrm{NaOH}$ and purification by preparative TLC chromatography on the silica gel. However, this simple attempt gave 6 with very low yield (only 5\%). We have exploited a different concept for the synthesis of $\mathbf{6}$ by alkylation of diester 5a with methyl iodide in the presence of triethylamine to $N$-methyl diester $\mathbf{1 3}$ and its subsequent saponification (Scheme 2).
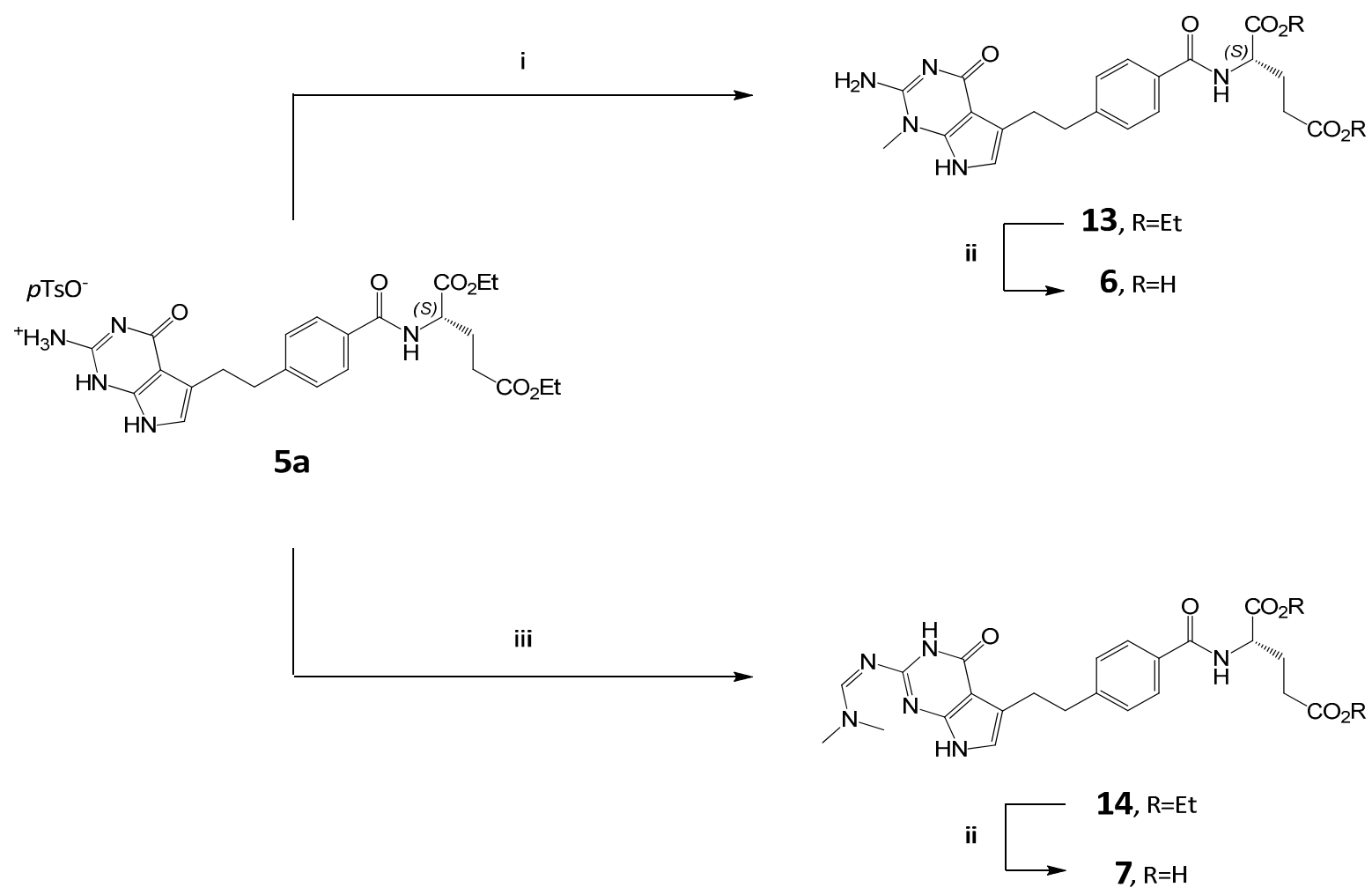

Scheme 2. Syntheses of impurities 6 and 7. Conditions: (i) $\mathrm{CH}_{3} \mathrm{I}, \mathrm{Et}_{3} \mathrm{~N}, \mathrm{DMF}$; (ii) (a) $\mathrm{NaOH}_{\mathrm{aq}}$, (b) $\mathrm{HCl}_{\mathrm{aq}}$; (iii) DMF-DMA, $p$-TSA, DMF.

\subsection{2. $N, N$-Dimethylformamide Impurity 7}

Recently, it has been reported [13] that when the condensation reaction between acid $\mathbf{2}$ and diethyl L-glutamate 4 is performed in the presence of $N, N$-dimethylformamide (DMF) as a solvent, it results in the formation $\mathbf{1 4}$ which subsequently after saponification results in the formation of impurity $\mathbf{7}$.

In order to prepare derivative 14, we adopted the procedure described in literature [13] which involved reacting 5a with dimethylformamide-dimethylacetal (DMF-DMA) in the presence of $p$-toluenesulfonic acid ( $p$-TSA) at $60{ }^{\circ} \mathrm{C}$. We found that high excess of $p$-TSA can be decreased from 10 to 1 equivalent (coming from $p$-TSA salt 5a). However, the addition of DMF and anhydrous conditions are required. After these modifications compound $\mathbf{1 4}$ was prepared in good yield and was converted to 7 by basic hydrolysis with $1 \mathrm{~N} \mathrm{NaOH}$ at room temperature followed by the acid treatment (Scheme 2) [15]. 


\subsubsection{Enantiomer of Pemetrexed $(\boldsymbol{R})-1$}

Compound $(\boldsymbol{R})-\mathbf{1}$, mentioned in Pharmacopeia, is a D-enantiomer of pemetrexed disodium. The presence of this impurity can be detected by a chiral HPLC method [8]. It probably arises from the trace amounts of D-enantiomer in commercial diethyl L-glutamate $\mathbf{4}$ or is formed during the hydrolysis of the ethyl esters of $\mathbf{1}$ in an alkaline medium at ambient or higher temperature (e.g., $\left.>30^{\circ}\right)$ [13]. This impurity was prepared starting from diethyl D-glutamate, following a synthetic process analogous to the synthesis of pemetrexed disodium (Scheme 1). Impurity $(\boldsymbol{R})-\mathbf{1}$ is characterized by the same ${ }^{1} \mathrm{H}-\mathrm{NMR},{ }^{13} \mathrm{C}-\mathrm{NMR}$ and mass spectrum as pemetrexed disodium.

\subsection{4. $\gamma$-Dipeptide Impurity 8}

In the course of our investigation on the pemetrexed disodium synthesis, we realized that the source of impurity $\mathbf{8}$ is $\alpha$-ethyl L-glutamate $\mathbf{1 1}$ which can be present in the starting diethyl L-glutamate 4. We envisioned that triacid $\mathbf{8}$ could result from the condensation of monoester $\mathbf{1 1}$ with the acid $\mathbf{2}$, followed by the formation of $\mathbf{1 9}$ through coupling $\alpha$-monoester of pemetrexed $\mathbf{1 8}$ with $\mathbf{4}$ and the saponification of the ethyl ester groups.

Our synthesis of impurity 8 includes first the preparation of $\alpha$-ethyl L-glutamate 11. The $N$-protected $\alpha$-ethyl ester 17 was isolated as the dicyclohexylammonium salt and purified by crystallization [16,17]. The decomposition of the salt with sulfuric acid and the removal of benzyloxycarbonyl-group (Cbz) by catalytic hydrogenolysis finally gave $\mathbf{1 1}$.

The conversion of $\mathbf{1 1}$ to 19a was achieved through conventional peptide coupling with CDMT/NMM and the subsequent formation of the $p$-TSA salt. The final hydrolysis of the triester 19a with $1 \mathrm{~N}$ $\mathrm{NaOH}$ followed by the acid treatment provided triacid $\mathbf{8}$ (Scheme 3).
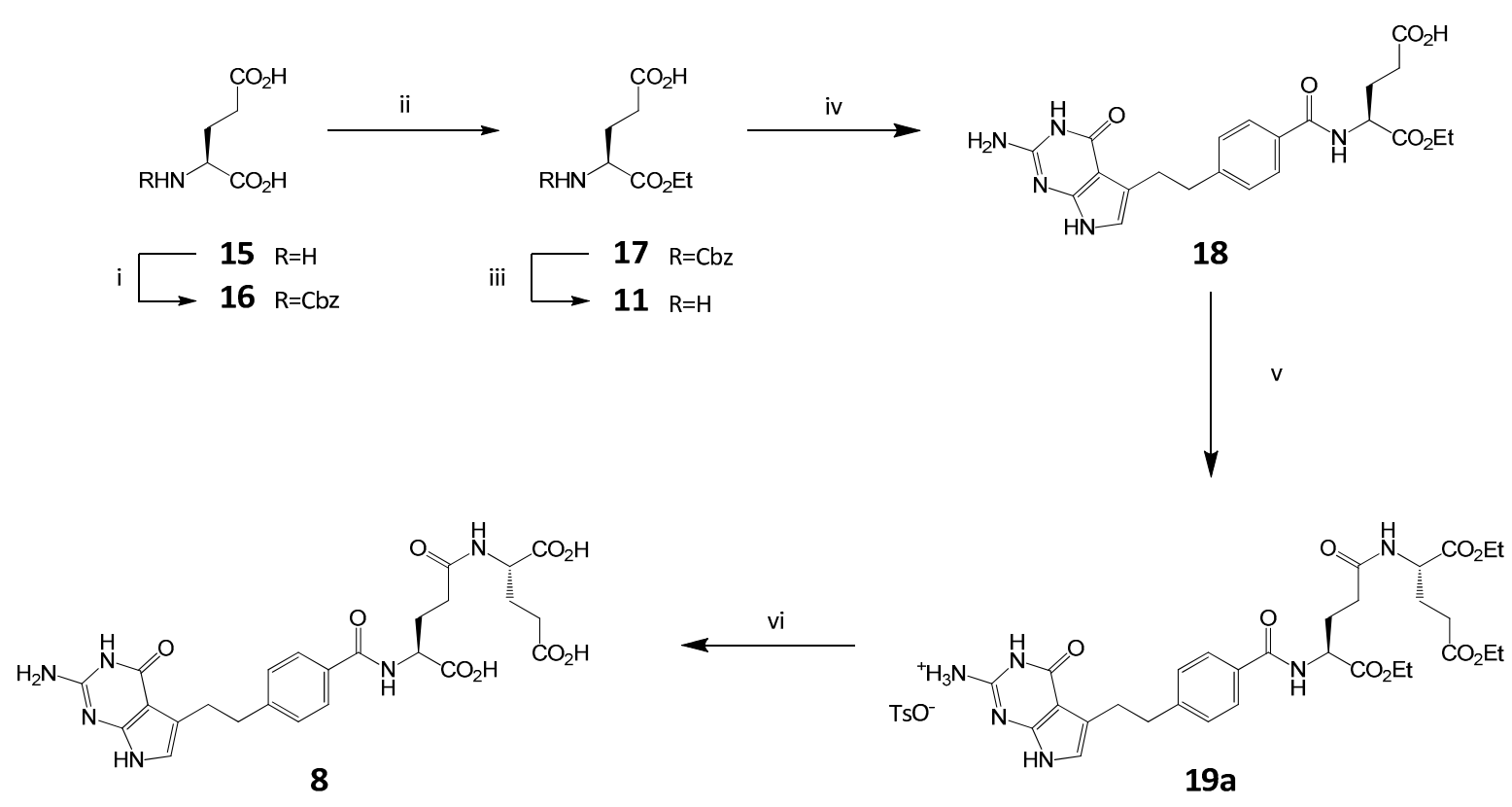

Scheme 3. Synthesis of impurity 8. Conditions: (i) $\mathrm{NaOH}, \mathrm{ClCO}_{2} \mathrm{Ph}$; (ii) (a) $\mathrm{Et}_{3} \mathrm{~N}, \mathrm{BrEt}$, $\mathrm{DMF}$, (b) $\mathrm{Cy}_{2} \mathrm{NH}$, (c) $1 \mathrm{M} \mathrm{H}_{2} \mathrm{SO}_{4 a q}$; (iii) $\mathrm{Pd} / \mathrm{C}$; (iv) 2, CDMT, NMM, DMF; (v) (a) 4, CDMT, NMM, DMF; (b) $p$-TSA, EtOH; (vi) (a) $\mathrm{NaOH}_{\text {aq }}$; (b) $\mathrm{HCl}_{\text {aq. }}$. 


\subsection{5. $\alpha$-Dipeptide Impurity 9}

Similarly, if starting diethyl L-glutamate $\mathbf{4}$ contains some amount of $\gamma$-ethyl L-glutamate $\mathbf{1 2}$, then during the preparation of pemetrexed disodium $\alpha$-dipeptide impurity 9 may appeared. At the beginning for the synthesis of dipeptide 9 a similar synthetic procedure to that described above for the preparation of dipeptide 8 was used (Scheme 4).

The reaction of $\gamma$-ethyl ester 12 (contamination of the main compound 4) with $\mathbf{2}$ led to $\gamma$-ethyl ester $\mathbf{2 0}$, which after further condensation with 4 gave $p$-toluenesulfonate 21a. This compound, after hydrolysis with $\mathrm{NaOH}$ at ambient temperature followed by acidification with $\mathrm{HCl}$, gave triacid 9.
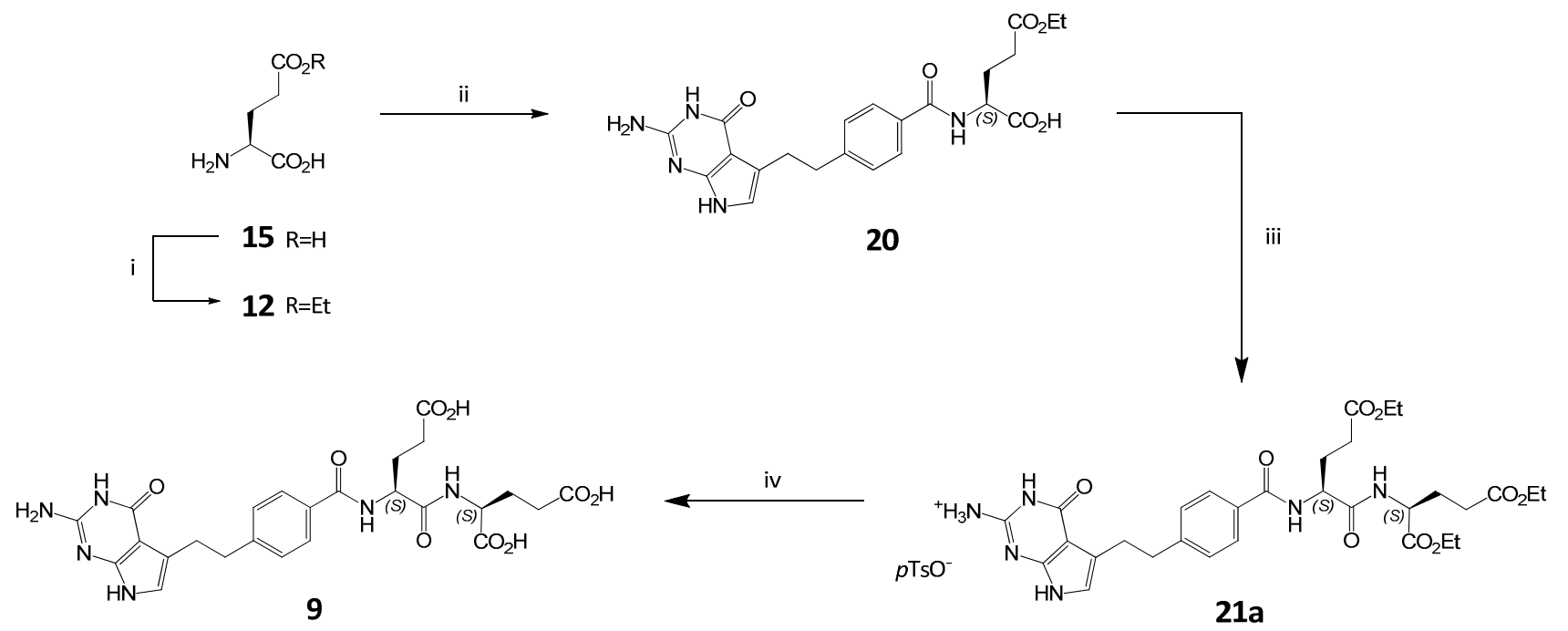

Scheme 4. Synthesis of impurity 9. Conditions: (i) HCl, EtOH; (ii) 2, CDMT, NMM, DMF; (iii) (a) 4, CDMT, NMM, DMF; (b) $p \mathrm{TsOH}, \mathrm{EtOH}$; (iv) (a) $1 \mathrm{M} \mathrm{NaOH}_{\mathrm{aq}}$, (b) $1 \mathrm{M} \mathrm{HCl}_{\mathrm{aq}}$

Surprisingly, the HPLC analysis of 9 revealed the presence of two separated equivalent peaks. For compound $\mathbf{8}$ such phenomenon was not observed. LC-MS showed that the molecular weight for both peaks of 9 was the same. In the NMR spectra of 21a and 9 we also observed doubled signals (for details, see Section 2.4).

One possible explanation of the observed data is the formation of diastereoisomeric mixture. Most probably monoester 20 (in fact the substituted benzoyl- $(S)-\alpha$-amino acid) undergoes a racemization during the activation/coupling step with diester 4 (Scheme 4, step iii) [18], thus a mixture of diastereoisomeric triesters 21 ( $S, S$ - and $R, S$-configuration) is formed which after hydrolysis give the mixture of diastereoisomeric triacids 9 ( $S, S$ - configuration and $R, S$-configuration), respectively.

A simple change in the coupling conditions to eliminate racemization in coupling $\mathbf{2 0}$ with amine $\mathbf{4}$ failed. Using HATU [19] instead of CDMT/NMM also resulted in the mixture of diastereoisomeric triesters 21. In order to resolve this problem and obtain standard samples, we decided to prepare independently both diastereoisomers of impurity $\mathbf{9}(\boldsymbol{S}, \boldsymbol{S}$ - and $\boldsymbol{S}, \boldsymbol{R}$-) employing a different synthetic route (Scheme 5).

In this approach $N$-Cbz-protected ( $\boldsymbol{S}$ or $\boldsymbol{R})$ glutamic acid derivatives were used for coupling leading to dipeptides $22(\boldsymbol{S}, \boldsymbol{S}$ - and $\boldsymbol{S}, \boldsymbol{R}$-) which were subsequently converted into $\mathbf{9}(\boldsymbol{S}, \boldsymbol{S}$ - and $\boldsymbol{S}, \boldsymbol{R}$-). It is well known that contrary to $\mathrm{N}^{\alpha}$-acyl protected amino acids which racemize readily during the 
activation/coupling of the carboxyl group for the amide bond formation, in the case of the urethane-type amine protecting groups (as Cbz) the tendency of racemization is largely suppressed [20].

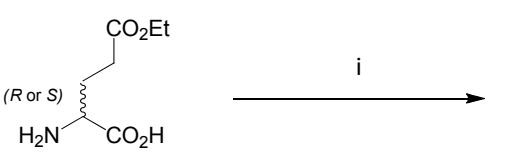

(S)-12

$(R)-12$

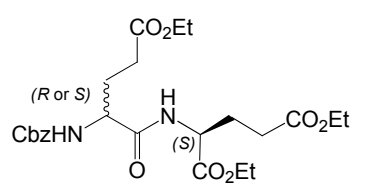

$(S, S)-22$

$(S, R)-22$

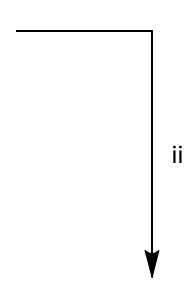

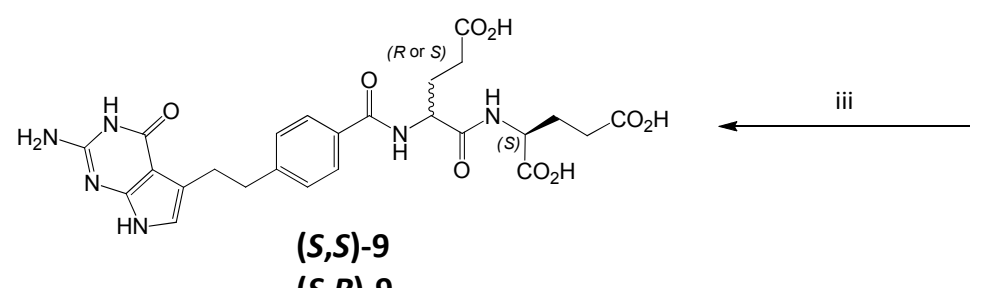

$(S, R)-9$

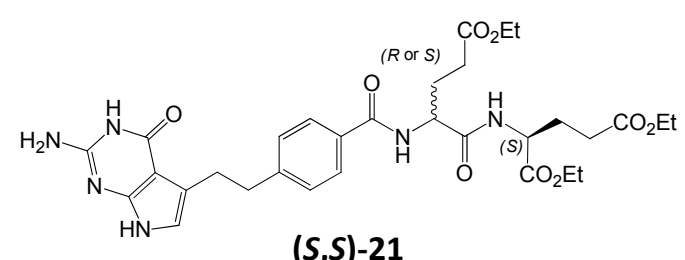

$(S, S)-21$

Scheme 5. Synthesis of $(\boldsymbol{S}, \boldsymbol{S})-\mathbf{9}$ and $(\boldsymbol{S}, \boldsymbol{R})-\mathbf{9}$. Conditions: (i) (a) $\mathrm{CbzCl}$, (b) 4, DIPEA, HATU, DMF (ii) (a) Pd/C, $\mathrm{H}_{2}, \mathrm{EtOH}$; (b) 2, HATU; (iii) (a) $1 \mathrm{M} \mathrm{NaOH}_{\mathrm{aq}}$, (b) $1 \mathrm{M} \mathrm{HClaq.}$

The $\gamma$-monoesters 12 (with $S$ - or $R$ - configuration, respectively) were $N$-Cbz-protected [21] and then coupled with diester 4 to obtain enantiomerically pure protected dipeptides $22(\boldsymbol{S}, \boldsymbol{S}$ - and $\boldsymbol{S}, \boldsymbol{R}$-). After cleaving the Cbz-group, each of the enantiomerically pure amines was coupled with acid $\mathbf{2}$ to give both diastereoisomeric triesters $\mathbf{2 1}$, which after hydrolysis led to diastereoisomeric triacids $(\boldsymbol{S}, \boldsymbol{S})-\mathbf{9}$ and $(\boldsymbol{S}, \boldsymbol{R})-\mathbf{9}$, respectively.

The NMR, MS and HPLC analyses confirmed that $(\boldsymbol{S}, \boldsymbol{S})-\mathbf{9}$ and $(\boldsymbol{S}, \boldsymbol{R})-\boldsymbol{9}$ were pure single compounds (in HPLC designated by different retention times 27.0 and $26.6 \mathrm{~min}$ for $(\boldsymbol{S}, \boldsymbol{S})-\mathbf{9}$ and $(\boldsymbol{S}, \boldsymbol{R})-\mathbf{9}$, respectively).

\subsubsection{Dimer Impurity 10}

Dimeric impurity 10 (as diasteroisomeric mixture) of pemetrexed might be formed during the basic hydrolysis of 5a to the pemetrexed disodium salt. According to the European Pharmacopoeia [8], in order to prepare impurities 10, pemetrexed disodium is dissolved in $0.1 \mathrm{M} \mathrm{NaOH}_{\text {aq }}$ and heated at $70{ }^{\circ} \mathrm{C}$ for $40 \mathrm{~min}$. After cooling to room temperature, the mother solution was diluted with water to obtain the "reference solution".

We have modified this procedure and developed a purification method for impurities 10. Pemetrexed disodium was dissolved in $0.1 \mathrm{M} \mathrm{NaOH}_{\mathrm{aq}}$ and heated under reflux for 3 days (TLC control). Then, the mixture was cooled and $10 \% \mathrm{HCl}_{\mathrm{aq}}$ was added to adjust $\mathrm{pH} \approx 3$. A formed precipitate was filtered and purified by chromatography to get the mixture of $\mathbf{1 0}$. The structure of the investigated compound was confirmed by NMR (discussed hereinafter). 


\subsection{Structure Elucidation by Analytical Methods}

The structures of all studied impurities were identified using the results of various 2D NMR spectra, including the COSY, ${ }^{1} \mathrm{H}_{-}{ }^{13} \mathrm{C} /{ }^{15} \mathrm{~N}$ gradient selected HSQC, as well as ${ }^{1} \mathrm{H}_{-}{ }^{13} \mathrm{C} /{ }^{15} \mathrm{~N}$ gradient selected HMBC sequences.

Enantiomeric impurity $(\boldsymbol{R})-\mathbf{1}$ : compound $(\boldsymbol{R})-\mathbf{1}$ in a diacid form as well as the disodium salt are the enantiomers of the main compound $\mathbf{1}$. The comparison of the multinuclear NMR spectra recorded for $(\boldsymbol{R})$-1 with those registered currently and published earlier for $(\boldsymbol{S})-\mathbf{1}[5,22]$ undoubtedly confirm the structure of the enantiomeric $(\boldsymbol{R})-\mathbf{1}$ (Table 2).

$N$-Methyl impurity 6: The analysis of the results of different NMR spectra, especially ${ }^{1} \mathrm{H}-{ }^{15} \mathrm{~N}$ HMBC experiment, strongly supports the proposed structure 6. The most significant effect was observed for the ${ }^{15} \mathrm{~N}-\mathrm{NMR}$ chemical shifts. Unfortunately, compound $\mathbf{6}$ (acid form) forms a gel in the DMSO solution and that is why we used NMR data of diethyl ester $\mathbf{1 3}$ for comparison. In the ${ }^{1} \mathrm{H}_{-}{ }^{15} \mathrm{~N}$ $g$-HMBC spectrum of $\mathbf{1 3}$ a strong correlation peak was noticed between the protons of $\mathrm{CH}_{3}$ group at $\delta=3.56 \mathrm{ppm}$ and nitrogen at $\delta=-274.2 \mathrm{ppm}$. This "cross-peak" identifies the position of the methylation which is an $\mathrm{N} 3$ nitrogen atom. Additionally, in the ${ }^{1} \mathrm{H}-{ }^{13} \mathrm{C} H M B C$ experiment $\mathrm{CH}_{3}$ protons (introduced onto nitrogen atom) correlate with two carbons $(\delta=152.1(\mathrm{C} 2)$ and $139.3 \mathrm{ppm}(\mathrm{C} 4))$ and as a consequence strongly support the place of the methylation.

Introducing a methyl group onto the N3 nitrogen atom causes a strong shielding increase noticeable for N3 and C4 nuclei by ca. 66 and 12 ppm, respectively. Similar shielding effects at C4 are visible in the case of $p$-toluenosulfonic salts $(\boldsymbol{R})-5 \mathbf{a}, \mathbf{2 1}$ a and 19a, (Experimental), which explains the protonation site of the neutral compounds at the N3 atom. The NMR data for $\mathbf{6} / \mathbf{1 3}$ are given in Table 2 .

$N, N$-Dimethylformamidine impurity 7: The sets of the ${ }^{1} \mathrm{H} /{ }^{13} \mathrm{C}$-NMR chemical shifts (whose assignment comes from the analysis of the results of more advanced $2 \mathrm{D}$ experiments, including ${ }^{1} \mathrm{H}_{-}{ }^{13} \mathrm{C}$ HSQC/HMBC and ${ }^{1} \mathrm{H}_{-}{ }^{15} \mathrm{~N}$ HSQC/HMBC correlations) unambiguously confirm the presence of an imine part in the molecule of the obtained compound and thereby the structure of impurity 7. The most important and significant effect was observed for the nitrogen nucleus at the $\mathrm{C} 2$ atom. The ${ }^{15} \mathrm{~N}$ shielding decrease of $c a .130 \mathrm{ppm}$ between the exocyclic nitrogen at $\mathrm{C} 2$ in the structures of 1 and 7 is responsible for the exchange of the nitrogen atom character from the amino to imine group. The comparison of ${ }^{1} \mathrm{H} /{ }^{13} \mathrm{C}$ - and ${ }^{15} \mathrm{~N}-\mathrm{NMR}$ data for $\mathbf{1}$ with that obtained for 7 (change of the $\mathrm{NH}_{2}$ group to $\left.\mathrm{N}=\mathrm{CH}-\mathrm{N}\left(\mathrm{CH}_{3}\right)_{2}\right)$, for which the ${ }^{1} \mathrm{H}-\mathrm{NMR}$ spectra are described in literature [13], leads to the observation of a few shielding/deshielding effects on the atoms in close neighborhood of the replacement. The most important one is carbon $\mathrm{C} 2$ deshielded by $c a .3 \mathrm{ppm}$ when compared with its position in 1. Moreover, a quite surprising deshielding effect is noticeable at the N1/H1 pair (Table 2). The $\mathrm{H} 1$ proton is deshielded by $c a .0 .6 \mathrm{ppm}$, whereas in the case of nitrogen N1 the same effect is stronger by $c a .13 \mathrm{ppm}$. Other more distant atoms also experience deshielding effects. For carbons $\mathrm{C} 5$, C8 and nitrogen N9 these changes are ca. 2 ppm, 1.5 ppm and $1.5 \mathrm{ppm}$, respectively (Table 2). 
Table 2. Comparison of the NMR data for compounds 1, 6, 7, 10 and 13 with the correlations observed in the HSQC and HMBC spectra.

\begin{tabular}{|c|c|c|c|c|c|c|c|c|c|c|c|}
\hline \multirow[t]{2}{*}{ Pos. ${ }^{a}$} & \multicolumn{2}{|r|}{1} & \multicolumn{2}{|r|}{$13^{b}$} & \multicolumn{2}{|c|}{$6^{\mathrm{b}}$} & \multicolumn{2}{|r|}{$7^{\mathrm{b}}$} & \multicolumn{2}{|r|}{10} & \multirow{2}{*}{ Pos. ${ }^{a}$} \\
\hline & ${ }^{1} \mathbf{H}(\mathbf{p p m})$ & ${ }^{13} \mathrm{C}^{15} \mathrm{~N}$ (ppm) & ${ }^{1} \mathrm{H}$ (ppm) & ${ }^{13} \mathrm{C} /{ }^{15} \mathrm{~N}$ (ppm) & ${ }^{1} \mathbf{H}(\mathrm{ppm})$ & ${ }^{13} \mathrm{C}^{\mathrm{c}}(\mathrm{ppm})$ & ${ }^{1} \mathrm{H}(\mathrm{ppm})$ & ${ }^{13} \mathrm{C} /{ }^{15} \mathrm{~N}$ (ppm) & ${ }^{1} \mathrm{H}(\mathrm{ppm})$ & ${ }^{13} \mathrm{C} /{ }^{15} \mathrm{~N}$ (ppm) & \\
\hline 1 & 10.18 & -235.7 & - & $\mathrm{d}$ & - & - & 10.78 & -222.3 & $10.09 ; 10.60$ & $-236.2 ;^{\mathrm{d}}$ & $1 ; 1^{\prime}$ \\
\hline 2 & - & 152.2 & - & 152.1 & - & 152.0 & - & 155.6 & - & $150.3 ; 152.1$ or 157.6 & $2 ; 2^{\prime}$ \\
\hline $\mathrm{C} 2-\mathrm{NH}_{2}$ & 6.03 & -310.8 & d & d & d & - & - & -176.1 & $6.02 ; 6.90$ & $-311 ;{ }^{\mathrm{d}}$ & $\begin{array}{l}\mathrm{C} 2-\mathrm{NH}_{2} \\
\mathrm{C} 2 '-\mathrm{NH}_{2}\end{array}$ \\
\hline 3 & - & -207.6 & & -274.2 & - & - & - & NR & - & d & $3 ; \mathbf{3}^{\prime}$ \\
\hline 4 & - & 151.3 & - & 139.3 & - & 139.0 & - & 150.1 & - & 152.1 or $157.6 ; 164.0$ & $4 ; 4^{\prime}$ \\
\hline 5 & - & 98.8 & - & 100.3 & - & 100.9 & - & 101.7 & - & $99.5 ; 92.71$ & $5 ; 5^{\prime}$ \\
\hline 6 & - & 159.4 & - & 163.3 & - & 163.8 & - & 160.2 & - & $159.1 ; 157.8$ & $6 ; 6^{\prime}$ \\
\hline 7 & - & 117.7 & - & 119.7 & - & 119.4 & - & 117.8 & - & $114.2 ; 51.7$ & $7 ; 7^{\prime}$ \\
\hline 8 & 6.32 & 113.5 & 6.64 & 114.9 & 6.42 & 113.2 & 6.47 & 115.0 & - & $123.0 ; 179.6$ & $8 ; 8^{\prime}$ \\
\hline 9 & 10.62 & -241.2 & - & -243.6 & - & - & 10.82 & -239.8 & $10.74 ; 10.87$ & $-238.9 ;-233.7$ & 9; $9^{\prime}$ \\
\hline 10 & 2.87 & 28.0 & 2.95 & 27.1 & 2.94 & 26.8 & 2.92 & 27.9 & $2.64 ; 2.57$ & $28.1 ; 34.2$ & $10 ; 10^{\prime}$ \\
\hline 11 & 2.99 & 36.2 & 3.00 & 35.8 & 2.99 & 35.6 & 3.01 & 36.2 & $2.67 ; 2.45$ & $37.8 ; 29.8$ & $11 ; 11^{\prime}$ \\
\hline 12 & - & 146.2 & - & 145.8 & - & $145.5^{\mathrm{e}}$ & - & 146.2 & - & $146.5 ; 145.0$ & $12 ; 12^{\prime}$ \\
\hline 13 & 7.30 & 128.2 & 7.32 & 128.2 & 7.28 & 127.7 & 7.31 & 128.2 & $7.26 ; 7.30$ & $128.0 ; 128.1$ & $13 ; 13^{\prime}$ \\
\hline 14 & 7.80 & 127.4 & 7.81 & 127.5 & 7.75 & 126.8 & 7.80 & 127.4 & 7.80 & $127.4+127.5$ & $14+14^{\prime}$ \\
\hline 15 & - & 131.3 & - & 131.2 & - & $131.5^{\mathrm{e}}$ & - & 131.3 & - & $131.4+131.5$ & $15+15^{\prime}$ \\
\hline 16 & - & 166.6 & - & 166.6 & - & 165.9 & - & 166.5 & - & $166.4+166.6$ & $16+16^{\prime}$ \\
\hline 17 & 8.52 & -265.9 & 8.65 & -266.8 & 8.12 & - & 8.51 & -265.9 & $2 \times 8.52$ & $2 \times-265.9$ & $17+17^{\prime}$ \\
\hline 18 & 4.41 & 52.0 & 4.44 & 52.0 & 4.39 & 52.1 & 4.41 & 51.9 & 4.41 & 51.9 & $18+18^{\prime}$ \\
\hline 19 & $1.97 ; 2.11$ & 26.0 & $2.02 ; 2.12$ & 25.7 & $2.00 ; 2.08$ & 26.4 & $1.96 ; 2.10$ & 26.0 & $1.97 ; 2.10$ & 26.0 & $19+19^{\prime}$ \\
\hline 20 & 2.37 & 30.4 & 2.44 & 30.2 & 2.34 & 30.6 & 2.36 & 30.5 & $2.32-2.40$ & 30.4 & $20+20^{\prime}$ \\
\hline C21-OH & d & 174.0 & - & 172.2 & d & 173.5 & 12.40 & 173.9 & $-/ 12.39$ & $173.9+173.9$ & $\mathrm{C} 21+21^{\prime}-\mathrm{OH}$ \\
\hline $\mathrm{C22}-\mathrm{OH}$ & $\mathrm{d}$ & 173.5 & - & 171.8 & d & 173.1 & 12.40 & 173.5 & $-/ 12.39$ & $173.5+173.5$ & $\mathrm{C} 22+22^{\prime}-\mathrm{OH}$ \\
\hline
\end{tabular}

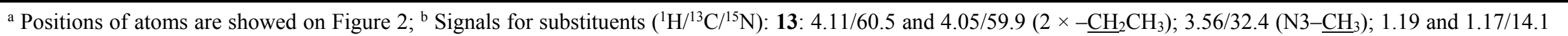
$\left(2 \times-\mathrm{CH}_{2} \underline{\mathrm{CH}}_{3}\right) ; 6$ : $\left.\left.3.49 / 31.5\left(\mathrm{~N} 3-\underline{\mathrm{CH}_{3}}\right) ; 7: 8.49 / 156.9-\mathrm{N}=\underline{\mathrm{CHN}}\left(\mathrm{CH}_{3}\right)_{2}\right) ;-281.2-\mathrm{N}=\mathrm{CHN}\left(\mathrm{CH}_{3}\right)_{2}\right) ; 3.01 / 34.5$ and 3.11/40.5 $\left(-\mathrm{N}=\mathrm{CHN}(\underline{\mathrm{CH}} 3)_{2}\right)$; ${ }^{\mathrm{c}}$ registered at $353 \mathrm{~K}$;

${ }^{\mathrm{d}}$ signals not observed; ${ }^{\mathrm{e}}$ Kjell et al. [12] described signal assignments for $\mathrm{C} 12$ and $\mathrm{C} 15$ in reversed order. 

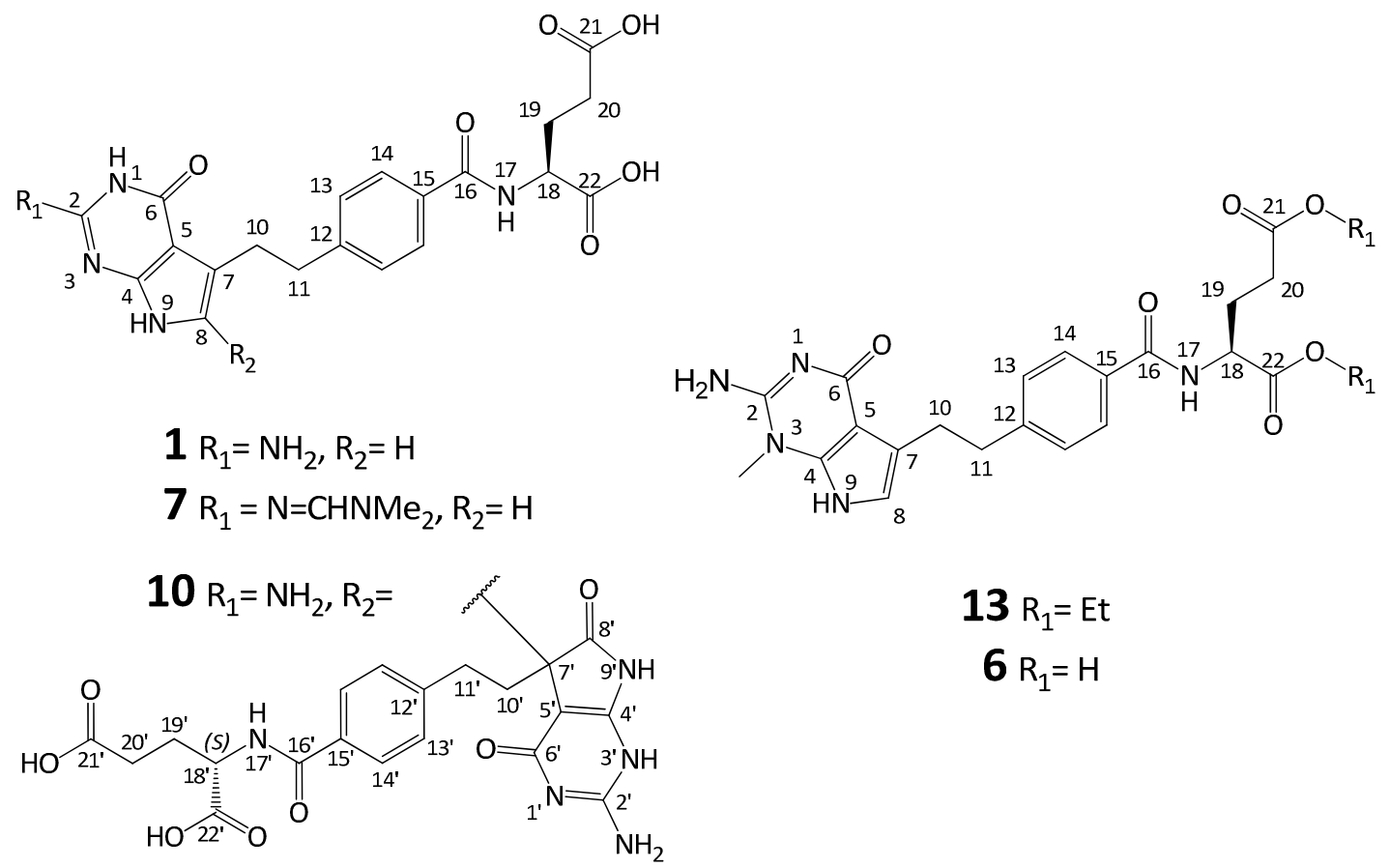

$13 \mathrm{R}_{1}=\mathrm{Et}$

$6 \mathrm{R}_{1}=\mathrm{H}$

Figure 2. Numbering of atoms in the NMR spectra description for compounds $\mathbf{1 , ~ 6 , ~ 7 , ~} 10$ and $\mathbf{1 3}$ (Table 2).

\section{$\gamma$-Dipeptide impurity 8 and $\alpha$-dipeptide impurities 9:}

The NMR spectra and HPLC analysis of compounds $\mathbf{8}$ and $\mathbf{9}$ showed some unexpected results. As mentioned before, in the case of impurity $\mathbf{8}$ the HPLC method revealed one compound, whereas for impurity 9 two peaks in HPLC were observed. A detailed analysis of the 2D-NMR experiments for 8 taken in the DMSO solution leads to the ${ }^{1} \mathrm{H} /{ }^{13} \mathrm{C}$ - and ${ }^{15} \mathrm{~N}-\mathrm{NMR}$ chemical shift assignment and complete confirmation of the structure of this impurity (Table 3 ).

The same detailed analysis of the 2D-NMR data was performed for $\mathbf{9}$, confirming the structure of this impurity, although a doubled set of ${ }^{1} \mathrm{H} /{ }^{13} \mathrm{C}-\mathrm{NMR}$ and even ${ }^{15} \mathrm{~N}-\mathrm{NMR}$ signals was noticed there.

At the beginning the observation of the doubled ${ }^{1} \mathrm{H} /{ }^{13} \mathrm{C}$-NMR signals forced us to check if we were not dealing with rotamers. A well-known method employing ${ }^{1} \mathrm{H}-\mathrm{NMR}$ spectroscopy [23] was useless, because the ${ }^{1} \mathrm{H}-\mathrm{NMR}$ signals overlapped. We decided to raise the temperature and observe the ${ }^{13} \mathrm{C}-\mathrm{NMR}$ spectrum. However, the temperature increase (between $25-100{ }^{\circ} \mathrm{C}$ or $298-373 \mathrm{~K}$ ) resulted in no significant changes in the ${ }^{1} \mathrm{H} /{ }^{13} \mathrm{C}$-NMR spectra and based on these experiments we ruled out the hypothesis of the rotamers presence.

Another possible explanation of the observed data was the formation of the diastereoisomeric mixture during the synthesis. To prove this hypothesis, both diastereoisomers of impurity $\mathbf{9}(\boldsymbol{S}, \boldsymbol{S}$ - and $\boldsymbol{S}, \boldsymbol{R}$-) were independently synthesized employing a substantially racemization-free synthetic route based on the use of the $N$-Cbz protecting group described in Section 2.3.5 (Scheme 5).

The NMR, MS and HPLC analysis of the synthesized compounds confirmed that $(\boldsymbol{S}, \boldsymbol{S})-\mathbf{9}$ and $(\boldsymbol{S}, \boldsymbol{R})-9$ were pure single diastereoisomers characterized by a single set of the ${ }^{1} \mathrm{H} /{ }^{13} \mathrm{C}$ - and ${ }^{15} \mathrm{~N}-\mathrm{NMR}$ signals. The ${ }^{1} \mathrm{H} /{ }^{13} \mathrm{C}-\mathrm{NMR}$ spectra recorded for both diastereoisomeric compounds $(\boldsymbol{S}, \boldsymbol{S})-\mathbf{9}$ and $(\boldsymbol{S}, \boldsymbol{R})-\mathbf{9}$ were very similar to each other, with minor differences in the narrow ranges of the ${ }^{1} \mathrm{H} /{ }^{13} \mathrm{C}-\mathrm{NMR}$ chemical shifts (Table 3). These are visible for the C16-C28 chain and especially for the H17-H20 and H23-H26 protons. 
Table 3. NMR Data for compounds $8,(\boldsymbol{S}, \boldsymbol{S})-\mathbf{9}$ and $(\boldsymbol{S}, \boldsymbol{R})-\mathbf{9}$ with the correlations observed in the HSQC and HMBC spectra.

\begin{tabular}{|c|c|c|c|c|c|c|c|c|}
\hline \multirow[b]{2}{*}{ Pos. ${ }^{a}$} & \multicolumn{2}{|r|}{8} & \multicolumn{4}{|c|}{$(S, S)-9$} & \multicolumn{2}{|c|}{$(S, R)-9$} \\
\hline & ${ }^{1} \mathbf{H}(\mathrm{ppm})$ & ${ }^{13} \mathrm{C} /{ }^{15} \mathbf{N}$ (ppm) & Pos. ${ }^{a}$ & ${ }^{1} \mathbf{H}(\mathrm{ppm})$ & ${ }^{13} \mathrm{C} /{ }^{15} \mathrm{~N}$ (ppm) & Pos. ${ }^{a}$ & ${ }^{1} \mathbf{H}(\mathrm{ppm})$ & ${ }^{13} \mathrm{C}$ (ppm) \\
\hline 1 & 10.18 & -236.4 & 1 & 10.17 & -236.3 & 1 & 10.15 & - \\
\hline 2 & - & 152.2 & 2 & - & 152.3 & 2 & - & 152.2 \\
\hline $\mathrm{C}_{2}-\mathrm{NH}_{2}$ & 6.03 & -311.2 & $\mathrm{C} 2-\mathrm{NH}_{2}$ & 6.01 & -311.1 & $\mathrm{C} 2-\mathrm{NH}_{2}$ & 6.01 & - \\
\hline 3 & - & -208.0 & 3 & - & -208.0 & 3 & - & - \\
\hline 4 & - & $151.3^{p}$ & 4 & - & 151.4 & 4 & - & 151.3 \\
\hline 5 & - & 98.8 & 5 & - & 98.8 & 5 & - & 98.7 \\
\hline 6 & - & 159.3 & 6 & - & 159.5 & 6 & - & 159.3 \\
\hline 7 & - & 117.6 & 7 & - & 117.5 & 7 & - & 117.7 \\
\hline 8 & 6.31 & 113.5 & 8 & 6.31 & 113.6 & 8 & 6.32 & 113.4 \\
\hline 9 & 10.61 & -241.4 & 9 & 10.60 & -241.4 & 9 & 10.60 & - \\
\hline 10 & 2.86 & 28.0 & 10 & 2.85 & 28.1 & 10 & 2.86 & 28.0 \\
\hline 11 & 2.96 & 36.1 & 11 & 2.97 & 36.2 & 11 & 2.98 & 36.1 \\
\hline 12 & - & 146.1 & 12 & - & 146.2 & 12 & - & 146.1 \\
\hline 13 & 7.29 & 128.2 & 13 & 7.28 & 128.2 & 13 & 7.28 & 128.1 \\
\hline 14 & 7.80 & 127.4 & 14 & 7.78 & 127.5 & 14 & 7.79 & 127.5 \\
\hline 15 & - & 131.4 & 15 & - & 131.5 & 15 & - & 131.5 \\
\hline 16 & - & 166.4 & 16 & - & 166.6 & 16 & - & 166.4 \\
\hline 17 & 8.57 & -265.6 & 17 & 8.34 & -265.5 & 17 & 8.30 & - \\
\hline 18 & 4.35 & 52.3 & 18 & 4.46 & 52.8 & 18 & $4.50(1 \mathrm{H}, \mathrm{m})$ & 52.8 \\
\hline 19 & $1.94+2.10$ & 26.5 & 19 & $1.92+2.03$ & 27.1 & 19 & $1.94+2.01$ & 27.2 \\
\hline 20 & 2.28 & 31.8 & 20 & 2.34 & 30.5 & 20 & 2.32 & 30.5 \\
\hline 21 & - & 171.8 & C21-OH & $\mathrm{c}$ & 174.3 & С21-OH & $\mathrm{c}$ & 174.1 \\
\hline $\mathrm{C22-OH}$ & $12.40^{\mathrm{b}}$ & 173.5 & 22 & - & 171.7 & 22 & - & 171.6 \\
\hline 23 & 8.15 & -260.0 & 23 & 8.21 & -263.2 & 23 & 8.20 & - \\
\hline 24 & 4.21 & 51.2 & 24 & 4.22 & 51.3 & 24 & 4.23 & 51.1 \\
\hline 25 & $1.75+1.93$ & 26.4 & 25 & $1.81+1.99$ & 26.3 & 25 & $1.79+1.99$ & 26.4 \\
\hline 26 & 2.27 & 30.1 & 26 & 2.30 & 30.1 & 26 & 2.25 & 29.9 \\
\hline C27-OH & $12.40^{b}$ & 173.8 & C27-OH & $\mathrm{c}$ & 173.9 & C27-OH & $\mathrm{c}$ & 173.7 \\
\hline C28-OH & $12.40^{b}$ & 173.4 & С28-OH & $\mathrm{c}$ & 173.3 & C28-OH & $\mathrm{c}$ & 173.1 \\
\hline
\end{tabular}

${ }^{a}$ Positions of atoms are showed on Figure $3 ;{ }^{b}$ probably one common signal for the exchanging protons of carboxylic groups; ${ }^{\mathrm{c}}$ signals not observed.

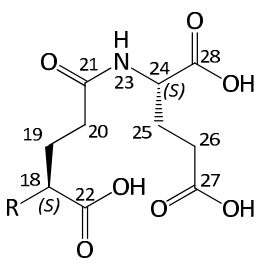

8

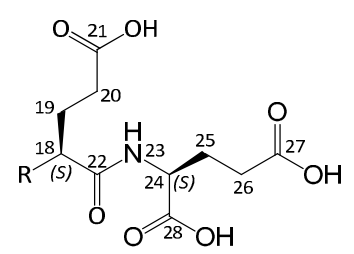

$(S, S)-9$
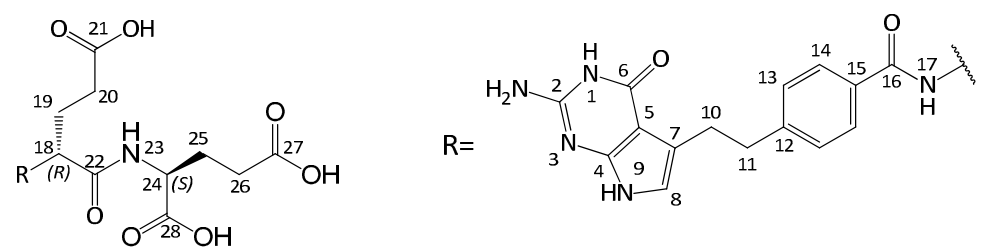

Figure 3. Numbering of atoms in the NMR spectra description for compounds $8,(\boldsymbol{S}, \boldsymbol{S})-\mathbf{9}$ and $(\boldsymbol{S}, \boldsymbol{R})-\mathbf{9}$ (Table 3). 
All the results strongly support the hypothesis that during the synthesis of impurity 9 according to Scheme 4 , the coupling of $\mathbf{2 0}$ with $\mathbf{4}$ leads to the diastereomeric mixture of $\mathbf{2 2}$.

Diasteroisomeric dimer impurity 10:This impurity was mentioned in Pharmacopeia but has not been reported in literature. The HR mass spectrum of $\mathbf{1 0}$ showed the exact mass $\mathrm{m} / \mathrm{z}=867.2709$, perfectly corresponding with the Pharmacopeia structure. Yet more convincing proof of the structure of $\mathbf{1 0}$ comes from the analysis of various NMR experiments. The ${ }^{1} \mathrm{H} /{ }^{13} \mathrm{C}$ spectra for this impurity in DMSO showed double sets of signals which may be considered as an existence of two structurally identical fragments. This observation and further analysis of the long-range ${ }^{1} \mathrm{H}-{ }^{13} \mathrm{C}$ and ${ }^{1} \mathrm{H}-{ }^{15} \mathrm{~N} g$ - $\mathrm{HMBC}$ correlations leading to ${ }^{1} \mathrm{H} /{ }^{13} \mathrm{C}$-and ${ }^{15} \mathrm{~N}-\mathrm{NMR}$ signals assignment, indicates that both "pemetrexed" parts in this structure are connected with each other via the $\mathrm{C} 7 / \mathrm{C} 8$ bond.

One part of this dimeric molecule looks identically as the pemetrexed molecule (both C7 $\delta=114.2 \mathrm{ppm}$ and $\mathrm{C} 8 \delta=123.0 \mathrm{ppm}$ carbons are aromatic), whereas in the second part carbons $\mathrm{C} 7$ and $\mathrm{C} 8$ change their character in such a way that $\mathrm{C} 7(\delta=51.7 \mathrm{ppm})$ becomes more aliphatic, while the $\mathrm{C} 8$ nucleus $(\delta=179.6 \mathrm{ppm})$ is much more deshielded than when they are positioned in the "pemetrexed" part (Table 2). The above mentioned effects are as follows: the shielding increase of $c a .62 \mathrm{ppm}$ and at the same time the shielding decrease of $c a .55 \mathrm{ppm}$ for $\mathrm{C} 7$ and $\mathrm{C} 8$, respectively.

\section{Experimental Section}

\subsection{General Information}

The starting 4-[2-(2-amino-4-oxo-4,7-dihydro-1H-pyrrolo[2,3- $d$ ]pyrimidin-5-yl)ethyl]benzoic acid (2) was obtained from Neorganic, Warsaw, Poland. $\gamma$-Ethyl L- and D-glutamates were prepared according to the literature procedure [21]. Other materials, solvents and reagents were of commercial origin and used without additional operations. All reactions were carried out in ambient temperature, if not stated otherwise. Coupling reactions were performed in anhydrous solvents.

The purity of the examined compounds was determined using HPLC/UHPLC methods with the chromatography system UltiMate ${ }^{\mathrm{TM}}$ 3000RS UHPLC (Dionex Corporation, Sunnyvale, CA, USA) equipped with an autosampler and a DAD 3000RS detector.

Method A: Gemini C18 column (150 mm $\times 4.6 \mathrm{~mm}, 3 \mu \mathrm{m}$; Phenomenex, Torrance, CA, USA) was placed in a thermostated column heater at $25{ }^{\circ} \mathrm{C}$. The mobile phases consisting of A $(4 \mathrm{~g} / \mathrm{L}$ dipotassium hydrogen phosphate; $\mathrm{pH}$ 5.2) and $\mathrm{B}$ (acetonitrile) were used with the gradient mode at the flow rate of $0.9 \mathrm{~mL} / \mathrm{min}$. The samples were prepared at a concentration of about $0.5 \mathrm{mg} / \mathrm{mL}$ and were diluted in $0.4 \mathrm{~g} / \mathrm{L}$ of dipotassium hydrogen phosphate. The injection volume was $10 \mu \mathrm{L}$. The UV detection at $230 \mathrm{~nm}$ was used.

The TLC separations were performed on the TLC silica gel 60 F254 on alumina sheets (Merck and/or Sigma-Aldrich). The visualization was performed by UV light (254 and/or $365 \mathrm{~nm}$ ) and [24].

The specific rotation $[\alpha]_{\mathrm{D}}$ was calculated from an optical rotation measurement performed on the Perkin Elmer 341 Polarimeter (PerkinElmer, Waltham, MA, USA) at the wavelength of $589 \mathrm{~nm}$ (D line of a sodium lamp), at $20{ }^{\circ} \mathrm{C}$.

The melting points were determined by differential scanning calorimetry (DSC) carried out by means of the DSC822 with an IntraCooler (Mettler Toledo GmbH, Schwerzenbach, Switzerland). 
The ${ }^{1} \mathrm{H}-\mathrm{NMR}(600 \mathrm{MHz}),{ }^{13} \mathrm{C}-\mathrm{NMR}(150 \mathrm{MHz})$ and 15N-NMR (60 MHz) spectra recorded in the DMSO- $d_{6}$ solutions with the Varian-NMR-vnmrs600 spectrometer (Varian Inc. Palo Alto, CA, USA) at $298 \mathrm{~K}$ temperature, equipped with a $600 \mathrm{MHz}$ PFG Auto XID $\left({ }^{1} \mathrm{H} /{ }^{15} \mathrm{~N}-{ }^{31} \mathrm{P} 5 \mathrm{~mm}\right)$ indirect probehead. To identify the structures of pemetrexed impurities correctly, careful analysis of the results of $1 \mathrm{D}$ and 2D NMR experiments was employed. The 1D and 2D measurements covered: ${ }^{1} \mathrm{H}$ selective NOESY, 2D: COSY, the ${ }^{1} \mathrm{H}-{ }^{13} \mathrm{C}$ gradient selected HSQC and $\mathrm{HMBC}$ optimized for ${ }^{1} J(\mathrm{C}-\mathrm{H})=150 \mathrm{~Hz}$ and ${ }^{\mathrm{n}} J(\mathrm{C}-\mathrm{H})=8 \mathrm{~Hz}$, respectively. The ${ }^{15} \mathrm{~N}$ NMR chemical shifts were obtained on the basis of the $2 \mathrm{D}$ ${ }^{1} \mathrm{H}-{ }^{15} \mathrm{~N}$ gradient selected HSQC and HMBC experiments, optimized for ${ }^{1} J(\mathrm{~N}-\mathrm{H})=90 \mathrm{~Hz}$ and ${ }^{\mathrm{n}} J(\mathrm{~N}-\mathrm{H})=6 \mathrm{~Hz}$, respectively. Standard experimental conditions and standard Varian programs (ChemPack 4.1) were used. The ${ }^{1} \mathrm{H}$ - and ${ }^{13} \mathrm{C}$-NMR chemical shifts are given relative to the TMS signal at $0.0 \mathrm{ppm}$, whereas neat nitromethane at $0.0 \mathrm{ppm}$ was used as a standard for the ${ }^{15} \mathrm{~N}-\mathrm{NMR}$ chemical shifts. The concentration of the solutions used for the measurements was about $20-30 \mathrm{mg}$ of the compounds in $0.6 \mathrm{~cm}^{3}$ of deuterated DMSO (DMSO- $d_{6}$ ). Used abbreviations: $\mathrm{s}$ - singlet, $\mathrm{d}$ - doublet, $\mathrm{t}$ - triplet, $\mathrm{m}$-multiplet, ov-overlapped signals. The integrals are not presented due to the signals overlapping in most cases. Some ${ }^{1} \mathrm{H}-\mathrm{NMR}$ chemical shifts for all the compounds studied are given as the averaged value of the center of multiplets read from the ${ }^{1} \mathrm{H}-{ }^{13} \mathrm{C}$-HSQC experiments.

The mass spectra were recorded on the MaldiSYNAPT G2-S HDMS (Waters Co., Milford, MA, USA) Spectrometer via electrospray ionization (ESI-MS).

\subsection{Synthesis of Impurity 6}

3.2.1. (2S)-2-[[4-[2-(2-Amino-1-methyl-4-oxo-4,7-dihydro-1H-pyrrolo[2,3-d]pyrimidin-5yl)ethyl]benzoyl]amino]pentanedioic Acid Diethyl Ester (13)

To the solution of $5 \mathbf{a}(6.0 \mathrm{~g}, 9.16 \mathrm{mmol})$ in DMF $(40 \mathrm{~mL})$ triethylamine was added $(3.20 \mathrm{~mL}$, $22.96 \mathrm{mmol})$, followed by methyl iodide $(2.06 \mathrm{~mL}, 33.09 \mathrm{mmol})$ and the solution was left at room temperature for $72 \mathrm{~h}$. Then $\mathrm{CH}_{2} \mathrm{Cl}_{2}(80 \mathrm{~mL})$ and water $(80 \mathrm{~mL})$ were added. The layers were separated and the aqueous layer was extracted with $\mathrm{CH}_{2} \mathrm{Cl}_{2}(1 \times 40 \mathrm{~mL})$. The combined organic layers were dried over anhydrous $\mathrm{MgSO}_{4}$ and concentrated. The residue was dissolved in $\mathrm{MeOH}(10 \mathrm{~mL})$ and ${ }^{i} \operatorname{Pr}_{2} \mathrm{O}$ $(50 \mathrm{~mL})$ was added. The resulted precipitate was filtered, washed with ${ }^{i} \operatorname{Pr}_{2} \mathrm{O}(2 \times 10 \mathrm{~mL})$, and dried to give 13 (4.0 g, 88\%).

TLC: $R_{\mathrm{F}}=0.18\left(\mathrm{CHCl}_{3} / \mathrm{MeOH} / \mathrm{Et}_{3} \mathrm{~N} 8: 2: 1\right)$

${ }^{1} \mathrm{H}-\mathrm{NMR}: \delta$ : $8.65(1 \mathrm{H}, \mathrm{d}, J=7.5 \mathrm{~Hz}, \mathrm{~N} 17-\mathrm{H}), 7.81(2 \mathrm{H}, \mathrm{d}, J=8.0 \mathrm{~Hz}, \mathrm{H} 14), 7.32(2 \mathrm{H}, \mathrm{d}$, $J=8.0 \mathrm{~Hz}, \mathrm{H} 13), 6.64(1 \mathrm{H}, \mathrm{s}, \mathrm{H} 8), 4.44(1 \mathrm{H}, \mathrm{m}, \mathrm{H} 18), 4.11\left(2 \mathrm{H}, \mathrm{m},-\mathrm{C}_{2} \mathrm{CH}_{3}\right.$ at $\left.\mathrm{C} 22\right), 4.05(2 \mathrm{H}, \mathrm{q}$, $J=7.1 \mathrm{~Hz},-\underline{\mathrm{CH}}_{2} \mathrm{CH}_{3}$ at $\left.\mathrm{C} 21\right), 3.56\left(3 \mathrm{H}, \mathrm{s}, \mathrm{CH}_{3}\right.$ group at $\left.\mathrm{N} 3\right), 3.00(2 \mathrm{H}, \mathrm{m}, \mathrm{H} 11), 2.95(2 \mathrm{H}, \mathrm{m}, \mathrm{H} 10)$, $2.44(2 \mathrm{H}, \mathrm{m}, \mathrm{H} 20), 2.12$ and $2.02(2 \mathrm{H}, 2 \times \mathrm{m}$, both $\mathrm{H} 19$ protons $), 1.19$ and $1.17(2 \times 3 \mathrm{H}, 2 \times \mathrm{q}, J=7.1 \mathrm{~Hz}$, both $\mathrm{CH}_{3}$ groups of $-\mathrm{CH}_{2} \mathrm{CH}_{3}$ at $\mathrm{C}_{2} 2$ and $\left.\mathrm{C} 21\right)$;

${ }^{13} \mathrm{C}-\mathrm{NMR}: \delta$ : 172.18 (CO, C21), 171.82 (CO, C22), 166.58 (CO, C16), 163.26 (probably C6), 152.11 (probably C2), 145.81 (C12), 139.31 (probably C4), 131.19 (C15), 128.17 (C13), 127.46 (C14), 119.69 (C7), 114.89 (C8), 100.31 (C5), $60.53\left(-\underline{\mathrm{CH}}_{2} \mathrm{CH}_{3}\right.$ at $\left.\mathrm{C} 22\right), 59.92\left(-\underline{\mathrm{CH}}_{2} \mathrm{CH}_{3}\right.$ at $\left.\mathrm{C} 21\right), 51.95$ (C18), 35.79 (C11), $32.45\left(\mathrm{CH}_{3}\right.$ group at N3), 30.17 (C20), 27.13 (C10), 25.69 (C19), $14.1\left(2 \times \mathrm{CH}_{3}\right.$ groups of $-\mathrm{CH}_{2} \mathrm{CH}_{3}$ at $\mathrm{C} 22$ and $\left.\mathrm{C} 21\right)$; 
${ }^{15} \mathrm{~N}-\mathrm{NMR} \delta$ : $-274.2(\mathrm{~N} 3),-266.8$ (N17), -243.6 (N9), the ${ }^{15} \mathrm{~N}-\mathrm{NMR}$ signals of $\mathrm{NH}_{2}$ at $\mathrm{C} 2$ and N1 not recorded in the ${ }^{1} \mathrm{H}_{-}{ }^{15} \mathrm{~N} g$-HSQC/HMBC experiments.

HRMS: calcd for $\mathrm{C}_{25} \mathrm{H}_{32} \mathrm{~N}_{5} \mathrm{O}_{6} m / z=498.2353$, found $m / z=498.2346$.

3.2.2. (2S)-2-[[4-[2-(2-Amino-1-methyl-4-oxo-4,7-dihydro-1H-pyrrolo[2,3-d]pyrimidin-5yl)ethyl]benzoyl]amino]pentanedioic Acid (6)

Compound 13 (3.50 g, $7.03 \mathrm{mmol})$ was treated with $1 \mathrm{M} \mathrm{NaOH}_{\mathrm{aq}}(30 \mathrm{~mL})$ and stirred at $R T$ for $2 \mathrm{~h}$. The reaction mixture was diluted with $\mathrm{EtOH}(30 \mathrm{~mL})$ and water $(30 \mathrm{~mL})$ and adjusted to $\mathrm{pH} 3.0$ with $1 \mathrm{M} \mathrm{HCl}$. The resulting slurry was heated to $60-65^{\circ} \mathrm{C}$ and then cooled to $R T$. The solid was filtered, washed with EtOH $(2 \times 10 \mathrm{~mL})$ and dried in vacuo at $40{ }^{\circ} \mathrm{C}$ for $24 \mathrm{~h}$. Crude 6 was purified by flash chromatography on a silica gel column using $\mathrm{CH}_{2} \mathrm{Cl}_{2} / \mathrm{MeOH} / \mathrm{H}_{2} \mathrm{O} / \mathrm{NH}_{3}$ as the mobile phase (40:40:5:2 $v / v)$. The respective fractions were collected and concentrated. The residue was dissolved in water $(50 \mathrm{~mL})$ and the $\mathrm{pH}$ was adjusted to $2-3$ with $1 \mathrm{M} \mathrm{HCl}$. EtOH $(220 \mathrm{~mL})$ was added and stirred for $30 \mathrm{~min}$. The suspension was filtered and the solid was washed with $\mathrm{EtOH} / \mathrm{H}_{2} \mathrm{O}(20 \mathrm{~mL})$ and dried at $40{ }^{\circ} \mathrm{C}$ to obtain $6(2.51 \mathrm{~g}, 81 \%$, HPLC purity $99.05 \%)$.

TLC: $R_{\mathrm{F}}=0.44,\left(\mathrm{CHCl}_{3} / \mathrm{MeOH} / \mathrm{NH}_{3}, 2: 2: 1\right)$.

Mp. $270{ }^{\circ} \mathrm{C}$;

$[\alpha]_{\mathrm{D}}^{20}=+10.03(\mathrm{c}=1, \mathrm{DMSO})$;

${ }^{1} \mathrm{H}-\mathrm{NMR}(353 \mathrm{~K}) \delta: 8.12(1 \mathrm{H}, \mathrm{s}, \mathrm{N} 17-\mathrm{H}), 7.75$ (2H, m, H14), 7.28 (2H, m, H13), 6.42 (1H, s, H8), 4.39 (1H, m, H18), 3.49 (3H, s, CH3 at N3), 2.99 (2H, m, H11), 2.94 (2H, m, H10), 2.34 (2H, m, H20), 2.08 and $2.00(2 \mathrm{H}, \mathrm{m}, \mathrm{H} 19)$;

${ }^{13} \mathrm{C}-\mathrm{NMR}(353 \mathrm{~K}) \delta: 173.54$ (CO, C21), 173.06 (CO, C22), 165.85 (CO, C16), 163.75 (C6), 152.04 (C2), 145.47 (C12), 139.03 (C4), 131.48 (C15), 127.72 (C13), 126.75 (C14), 119.43 (C7), 113.18 (C8), 100.94 (C5), 52.06 (C18), 35.63 (C11), 31.53 (N3-CH3), 30.59 (C20), 26.77 (C10), 26.41 (C19);

HRMS: calcd for $\mathrm{C}_{21} \mathrm{H}_{24} \mathrm{~N}_{5} \mathrm{O}_{6} \mathrm{~m} / z=442.1727$, found $m / z=442.1724$.

FT-IR: [cm ${ }^{-1}$ ] 3226-3127 (N-Hv, O-H $)_{v} ; 2926\left(\mathrm{C}-\mathrm{H}_{v}\right) ; 1682-1640\left(\mathrm{C}=\mathrm{O}_{v}, \mathrm{C}=\mathrm{N}_{v}\right) ; 1612 ; 1504$ $\left(\mathrm{C}=\mathrm{C}_{v}\right) ; 1543\left(\mathrm{~N}-\mathrm{H}_{\delta}, \mathrm{C}=\mathrm{N}_{v}\right) ; 1450-1402\left(\mathrm{C}-\mathrm{H}_{\delta}, \mathrm{C}-\mathrm{N}_{v}\right) ; 1236\left(\mathrm{C}-\mathrm{O}_{v}\right) ; 697\left(\mathrm{C}-\mathrm{H}_{\gamma}, \mathrm{N}-\mathrm{H}_{\gamma}\right)$.

\subsection{Synthesis of Impurity 7}

3.3.1. (2S)-2-[[4-[2-(2-(Dimethylamino)methyleneamino-4-oxo-4,7-dihydro-1H-pyrrolo[2,3d]pyrimidin-5-yl)ethyl]benzoyl]amino]pentanedioic Acid Diethyl Ester (14)

Compound 5a (6.5 g, $9.9 \mathrm{mmol})$ was suspended in $N, N$-dimethylformamide dimethyl acetal (DMF-DMA, $56 \mathrm{~mL}$ ) and anhydrous DMF $(18 \mathrm{~mL})$ and stirred at $R T$ for 3 days (TLC control). The reaction mixture was poured into water $(100 \mathrm{~mL})$ and extracted with $\mathrm{CH}_{2} \mathrm{Cl}_{2}(3 \times 30 \mathrm{~mL})$. The combined organic layers were dried over anhydrous $\mathrm{Na}_{2} \mathrm{SO}_{4}$ overnight, then filtered and concentrated to a thick liquid mass. Water $(100 \mathrm{~mL})$ was added to the mass and stirred (the use of a mechanical stirrer or a rotary evaporator is recommended) for $4 \mathrm{~h}$ at $R T$. The solid precipitate was filtered off and washed with water $(25 \mathrm{~mL})$, then dried. The solid was dissolved in $\mathrm{MeOH}(30 \mathrm{~mL})$ in $60-65^{\circ} \mathrm{C}$ and ${ }^{\mathrm{i}} \operatorname{Pr}_{2} \mathrm{O}(250 \mathrm{~mL})$ was slowly added (over $\left.45-60 \mathrm{~min}\right)$, then the mixture was cooled and 
stirred for $1 \mathrm{~h}$ at $R T$. The obtained precipitate was filtered and washed with ${ }^{i} \operatorname{Pr}_{2} \mathrm{O}(2 \times 15 \mathrm{~mL})$ and dried under vacuum at $40{ }^{\circ} \mathrm{C}$ to afford $14(4.37 \mathrm{~g}, 81.5 \%)$.

TLC: $R_{\mathrm{F}}=0.78\left(\mathrm{CHCl}_{3} / \mathrm{MeOH}, 8: 2\right)$;

Mp. $193{ }^{\circ} \mathrm{C}$;

${ }^{1} \mathrm{H}-\mathrm{NMR} \delta: 10.82(1 \mathrm{H}, \mathrm{s}, \mathrm{N} 9-\mathrm{H}), 10.77(1 \mathrm{H}, \mathrm{s}, \mathrm{N} 1-\mathrm{H}), 8.63(1 \mathrm{H}, \mathrm{d}, J=7.4 \mathrm{~Hz}), 8.49(1 \mathrm{H}, \mathrm{s}$, $\left.-\mathrm{N}=\mathrm{C} \underline{\mathrm{H}}-\mathrm{N}\left(\mathrm{CH}_{3}\right)_{2}\right), 7.79(2 \mathrm{H}, \mathrm{m}, \mathrm{H} 14), 7.31(2 \mathrm{H}, \mathrm{m}, \mathrm{H} 13), 6.46(1 \mathrm{H}, \mathrm{s}, \mathrm{H} 8), 4.43(1 \mathrm{H}, \mathrm{m}, \mathrm{H} 18), 4.11$ $\left(2 \mathrm{H}, \mathrm{m}, \mathrm{CH}_{2}\right.$ of $-\mathrm{CH}_{2} \mathrm{CH}_{3}$ at $\left.\mathrm{C} 22\right), 4.05\left(2 \mathrm{H}, \mathrm{q}, J=7.1 \mathrm{~Hz}, \mathrm{CH}_{2}\right.$ of $-\mathrm{CH}_{2} \mathrm{CH}_{3}$ at $\left.\mathrm{C} 21\right), 3.12(3 \mathrm{H}, \mathrm{s}$, one of the $\mathrm{CH}_{3}$ group of $\left.-\mathrm{N}=\mathrm{C} \underline{\mathrm{H}}-\mathrm{N}\left(\mathrm{CH}_{3}\right)_{2}\right), 3.01\left(5 \mathrm{H}, \mathrm{m}\right.$, one of the $\mathrm{CH}_{3}$ group of $\left.-\mathrm{N}=\mathrm{C} \underline{\mathrm{H}}-\mathrm{N}\left(\mathrm{CH}_{3}\right)_{2}\right)$ and both H11), 2.92 (2H, m, both H10), 2.44 (2H, m, both H20), 2.11 and 2.01 (2H, $2 \times$ m, both H19), $1.19\left(3 \mathrm{H}, \mathrm{s}, \mathrm{CH}_{3}\right.$ of $-\mathrm{CH}_{2} \mathrm{CH}_{3}$ at $\left.\mathrm{C} 22\right)$ and $1.17\left(3 \mathrm{H}, \mathrm{s}, \mathrm{CH}_{3}\right.$ of $-\mathrm{CH}_{2} \mathrm{CH}_{3}$ at $\left.\mathrm{C} 21\right)$;

${ }^{13} \mathrm{C}-\mathrm{NMR} \delta$ : 172.20 (CO, C21), 171.82 (CO, C22), 166.62 (CO, C16), 160.11 (probably C4), $156.91\left(-\mathrm{N}=\underline{\mathrm{CH}}-\mathrm{N}\left(\mathrm{CH}_{3}\right)_{2}\right), 155.52$ (C2), 150.06 (probably C6), 146.28 (C12), 131.10 (C15), 128.18 (C13), 127.39 (C14), 117.73 (C7), 114.93 (C8), 101.64 (C5), $60.51\left(\mathrm{CH}_{2}\right.$ of $-\mathrm{O}-\mathrm{CH}_{2} \mathrm{CH}_{3}$ at C22), 59.90 $\left(\mathrm{CH}_{2}\right.$ of $-\mathrm{CH}_{2} \mathrm{CH}_{3}$ at $\left.\mathrm{C} 21\right), 51.95(\mathrm{C} 18), 40.44$ (one of $\mathrm{CH}_{3}$ group of $\left.-\mathrm{N}=\mathrm{CH}-\mathrm{N}\left(\mathrm{CH}_{3}\right)_{2}\right), 36.17(\mathrm{C} 11)$, 34.43 (one of $\mathrm{CH}_{3}$ group of $-\mathrm{N}=\mathrm{CH}-\mathrm{N}\left(\mathrm{CH}_{3}\right)_{2}$ ), 30.17 (C20), 27.89 (C10), 25.70 (C19), 14.05 (both $\mathrm{CH}_{3}$ groups of $-\mathrm{CH}_{2} \mathrm{CH}_{3}$ at $\mathrm{C} 22$ and $\left.\mathrm{C} 21\right)$;

${ }^{15} \mathrm{~N}-\mathrm{NMR} \delta$ : $-281.3\left(-\mathrm{N}=\mathrm{CH}-\underline{\mathrm{N}}\left(\mathrm{CH}_{3}\right)_{2}\right),-266.9(\mathrm{~N} 17),-240.0(\mathrm{~N} 9),-175.8\left(-\underline{\mathrm{N}}=\mathrm{CH}-\mathrm{N}\left(\mathrm{CH}_{3}\right)_{2} . \mathrm{N} 1\right.$ and $\mathrm{N} 3$ not recorded in the ${ }^{1} \mathrm{H}_{-}{ }^{15} \mathrm{~N} g$-HMBC experiment;

HRMS: calcd for $\mathrm{C}_{27} \mathrm{H}_{35} \mathrm{~N}_{6} \mathrm{O}_{6} \mathrm{~m} / z=539.2618$, found $m / z=539.2610$.

3.3.2. (2S)-2-[[4-[2-(2-(Dimethylamino)methyleneamino-4-oxo-4,7-dihydro-1H-pyrrolo[2,3d]pyrimidin-5-yl)ethyl]benzoyl]amino]pentanedioic Acid (7)

Compound $14(0.77 \mathrm{~g}, 1.43 \mathrm{mmol})$ was treated with $\mathrm{NaOH}_{\mathrm{aq}}\left(0.25 \mathrm{~g}\right.$ in $\left.11 \mathrm{~mL} \mathrm{H} \mathrm{H}_{2} \mathrm{O}\right)$, the mixture was cooled to $0-5{ }^{\circ} \mathrm{C}$ and stirred for $15 \mathrm{~min}$. EtOH $(11 \mathrm{~mL})$ was added to the solution and stirred for $1 \mathrm{~h}$ at $0-5{ }^{\circ} \mathrm{C}$. The $\mathrm{pH}$ was adjusted to 3 with $1 \mathrm{~N} \mathrm{HCI}$, then $\mathrm{EtOH}$ was evaporated. The suspension was filtered and the solid was washed with $\mathrm{EtOH}: \mathrm{H}_{2} \mathrm{O}(1: 1,1 \times 5 \mathrm{~mL})$ and dried at $40^{\circ} \mathrm{C}$ to obtain $7(0.41 \mathrm{~g}$, $70.0 \%$, HPLC purity $80.0 \%$ ).

TLC: $R_{\mathrm{F}}=0.49\left(\mathrm{CHCl}_{3} / \mathrm{MeOH}, 1: 2\right)$;

NMR data are shown in Table 2.

${ }^{1} \mathrm{H}-\mathrm{NMR}$ (600 MHz, DMSO): 12.4 (2H, broad s, probably protons of both $\mathrm{COOH}$ groups), 10.82 $(1 \mathrm{H}, \mathrm{d}, J=1.8 \mathrm{~Hz}, \mathrm{~N} 9-\mathrm{H}), 10.78(1 \mathrm{H}, \mathrm{s}, \mathrm{N} 1-\mathrm{H}), 8.51(1 \mathrm{H}, \mathrm{d}, J=7.7 \mathrm{~Hz}, \mathrm{~N} 17-\mathrm{H}), 8.49(1 \mathrm{H}, \mathrm{s}$, $\left.-\mathrm{N}=\mathrm{C} \underline{\mathrm{H}}-\mathrm{N}\left(\mathrm{CH}_{3}\right)_{2}\right), 7.80(2 \mathrm{H}, \mathrm{m}, \mathrm{H} 14), 7.31(2 \mathrm{H}, \mathrm{m}, \mathrm{H} 13), 6.47(1 \mathrm{H}, \mathrm{d}, J=1.8 \mathrm{~Hz}, \mathrm{H} 8), 4.41(1 \mathrm{H}, \mathrm{m}$, $\mathrm{H} 18), 3.11\left(3 \mathrm{H}, \mathrm{s}\right.$, one of the $\mathrm{CH}_{3}$ groups of $\left.-\mathrm{N}=\mathrm{CH}-\mathrm{N}\left(\mathrm{CH}_{3}\right)_{2}\right), 3.01\left(5 \mathrm{H}, \mathrm{m}\right.$, one of the $\mathrm{CH}_{3}$ groups of $-\mathrm{N}=\mathrm{CH}-\mathrm{N}\left(\mathrm{CH}_{3}\right)_{2}$ and both protons at $\left.\mathrm{C} 11\right), 2.92(2 \mathrm{H}, \mathrm{m}, \mathrm{H} 10), 2.36(2 \mathrm{H}, \mathrm{t}, J=7.5 \mathrm{~Hz}, \mathrm{C} 20), 2.10$ $(1 \mathrm{H}, \mathrm{m}$, one of the protons at $\mathrm{C} 19), 1.96(1 \mathrm{H}, \mathrm{m}$, one of the protons at $\mathrm{C} 19)$;

${ }^{13} \mathrm{C}-\mathrm{NMR}$ (150 MHz, DMSO): 173.92 (CO, C21), 173.50 (CO, C22), 166.52 (CO, C16), 160.16 (probably C6), $156.94\left(-\mathrm{N}=\underline{\mathrm{C}} \mathrm{H}-\mathrm{N}\left(\mathrm{CH}_{3}\right)_{2}\right), 155.55$ (C2), 150.10 (probably $\left.\mathrm{C} 4\right), 146.17$ (C12), 131.34 (C15), 128.20 (C13), 127.38 (C14), 117.76 (C7), 115.00 (C8), 101.67 (C5), 51.91 (C18), 40.47 (one of the $\mathrm{CH}_{3}$ groups of $\left.-\mathrm{N}=\mathrm{CH}-\mathrm{N}\left(\mathrm{CH}_{3}\right)_{2}\right), 36.20(\mathrm{C} 11), 34.47$ (one of the $\mathrm{CH}_{3}$ groups of $-\mathrm{N}=\mathrm{CH}-\mathrm{N}\left(\mathrm{CH}_{3}\right)_{2}$ ), 30.45 (C20), 27.94 (C10), 25.95 (C19); 
${ }^{15} \mathrm{~N}-\mathrm{NMR}: \quad-281.2 \quad\left(-\mathrm{N}=\mathrm{CH}-\underline{\mathrm{N}}\left(\mathrm{CH}_{3}\right)_{2}\right), \quad-265.9 \quad(\mathrm{~N} 17), \quad-239.8 \quad(\mathrm{~N} 9), \quad-222.3 \quad(\mathrm{~N} 1),-176.1$ $\left(-\underline{N}=\mathrm{CH}-\mathrm{N}\left(\mathrm{CH}_{3}\right)_{2}\right), \mathrm{N} 3$ not recorded in ${ }^{1} \mathrm{H}_{-}{ }^{15} \mathrm{~N} g-\mathrm{HSQC} / \mathrm{HMBC}$ experiments;

HRMS: calcd for $\mathrm{C}_{23} \mathrm{H}_{27} \mathrm{~N}_{6} \mathrm{O}_{6} \mathrm{~m} / z=483.1992$, found $m / z=483.1985$.

FT-IR: $v\left[\mathrm{~cm}^{-1}\right]$ 3320-3126(N-H, $\left.\mathrm{O}-\mathrm{H}_{v}\right) ; 2922\left(\mathrm{C}-\mathrm{H}_{v}\right) ; 1683\left(\mathrm{C}=\mathrm{O}_{v}\right) ; 1635\left(\mathrm{C}=\mathrm{N}_{v}\right) ; 1532(\mathrm{~N}-\mathrm{H} \delta$, $\left.\mathrm{C}=\mathrm{N}_{v}\right) ; 1505\left(\mathrm{C}=\mathrm{C}_{v}\right) ; 1420\left(\mathrm{C}-\mathrm{H}_{\delta}\right) ; 1354\left(\mathrm{C}-\mathrm{N}_{v}\right) ; 1120\left(\mathrm{C}-\mathrm{O}_{v}\right) ; 840\left(\mathrm{C}-\mathrm{H}_{\gamma}\right)$.

Adjusting the reaction mixture's $\mathrm{pH}$ to 8 enabled the isolation of trisodium salt $7 \mathbf{a}$ (details are given in the Supplementary Part).

\subsection{Synthesis of Impurity $(\boldsymbol{R})-\mathbf{1}$}

3.4.1. (2R)-2-[[4-[2-(2-Amino-4-oxo-4,7-dihydro-1H-pyrrolo[2,3- $d]$ pyrimidin-5yl)ethyl]benzoyl]amino]-pentanedioic Acid Diethyl Ester, $p$-TSA Salt ((R)-5a)

$N$-methylmorpholine (NMM, $10.6 \mathrm{~mL}, 96.41 \mathrm{mmol})$ was added to the suspension of 2 (10 $\mathrm{g}$, $33.56 \mathrm{mmol})$ in DMF $(16 \mathrm{~mL})$ and $\mathrm{CH}_{2} \mathrm{Cl}_{2}(95 \mathrm{~mL})$, followed by 2-chloro-4,6-dimethoxy-1,3,5-triazine (CDMT, $6.48 \mathrm{~g}, 36.90 \mathrm{mmol}$ ), and the resulting solution was stirred at $38-40{ }^{\circ} \mathrm{C}$ for $2 \mathrm{~h}$. To this solution diethyl D-glutamate hydrochloride $(7.88 \mathrm{~g}, 32.87 \mathrm{mmol})$ was added and the resulting mixture was stirred for $2 \mathrm{~h}$. Then water $(100 \mathrm{~mL})$ was added and the mixture was stirred for $15 \mathrm{~min}$. The organic layer was separated and the aqueous phase extracted with $\mathrm{CH}_{2} \mathrm{Cl}_{2}(1 \times 70 \mathrm{~mL})$. The organic layers were collected, washed with $1 \mathrm{M} \mathrm{NaHCO}_{3 \text { aq }}(1 \times 70 \mathrm{~mL})$, and concentrated under reduced pressure to afford oil.

EtOH $(180 \mathrm{~mL})$ was added to the oil, followed by the solution of the $p$-toluenesulfonic acid monohydrate in EtOH (15.96 $\mathrm{g}$ in $180 \mathrm{~mL})$ and the resulting suspension was heated under reflux for $2 \mathrm{~h}$. The mixture was cooled to RT, the crystals of $(\boldsymbol{R})-\mathbf{5 a}$ were filtered and washed with EtOH $(2 \times 60 \mathrm{~mL})$. The wet cake was reslurried in EtOH $(400 \mathrm{~mL})$, refluxed for $1 \mathrm{~h}$ and cooled to $R T$. The crystals were filtered, washed with EtOH $(2 \times 60 \mathrm{~mL})$ and dried in vacuo at $40{ }^{\circ} \mathrm{C}$ for $24 \mathrm{~h}$ to provide $(\boldsymbol{R})-\mathbf{5 a}(14.48 \mathrm{~g}, 66 \%)$.

TLC: $R_{\mathrm{F}}=0.51\left(\mathrm{CHCl}_{3} / \mathrm{MeOH} 8: 2\right)$;

$[\alpha]_{\mathrm{D}}^{20}=+0.79(\mathrm{c}=1, \mathrm{DMSO})$;

Mp. $268^{\circ} \mathrm{C}$;

NMR data are identical as for the L-enantiomer $(\boldsymbol{S})-\mathbf{5 a}$;

HRMS: calcd for $\mathrm{C}_{24} \mathrm{H}_{30} \mathrm{~N}_{5} \mathrm{O}_{6} \mathrm{~m} / z=484.2196$, found $m / z=484.2187$.

3.4.2. (2R)-2-[[4-[2-(2-Amino-4-oxo-4,7-dihydro- $1 H$-pyrrolo[2,3- $d]$ pyrimidin-5yl)ethyl]benzoyl]amino]-pentanedioic Acid ((R)-1)

Compound $(\boldsymbol{R})-5 a(14.4 \mathrm{~g}, 21.98 \mathrm{mmol})$ was treated with $1 \mathrm{M} \mathrm{NaOHaq}(112 \mathrm{~mL})$, the mixture was stirred at room temperature. After $1 \mathrm{~h}$ the reaction mixture was adjusted to $\mathrm{pH} 8.0$ with $1 \mathrm{~N} \mathrm{HCl}$ aq and heated to $55-60{ }^{\circ} \mathrm{C}$. EtOH $(560 \mathrm{~mL})$ was added to the solution. After cooling to $R T$, the precipitated solid was collected by filtration and washed with EtOH $(2 \times 80 \mathrm{~mL})$. The wet solid $(12.84 \mathrm{~g})$ was dissolved in water $(120 \mathrm{~mL})$ and the solution was heated to $55-60{ }^{\circ} \mathrm{C}$. EtOH $(500 \mathrm{~mL})$ was added and then the mixture cooled to $R T$. The solid was filtered, washed with EtOH $(2 \times 80 \mathrm{~mL})$ and dried in vacuo at $35{ }^{\circ} \mathrm{C}$ for $48 \mathrm{~h}$ to provide $(\boldsymbol{R})-\mathbf{1}(9.8 \mathrm{~g}, 87 \%, 99.4 \%$ total HPLC purity, $99.9 \%$ chiral HPLC purity). 
Mp. $240{ }^{\circ} \mathrm{C}$;

$[\alpha]_{\mathrm{D}}^{20}=-18.5\left(\mathrm{c}=1, \mathrm{H}_{2} \mathrm{O}\right)$;

NMR data are identical as for L-enantiomer $(\boldsymbol{S})-\mathbf{1}$;

HRMS: calcd for $\mathrm{C}_{20} \mathrm{H}_{21} \mathrm{~N}_{5} \mathrm{O}_{6} \mathrm{Na} m / z=450.1390$, found $\mathrm{m} / z=450.1405$;

\subsection{Synthesis of Impurity $\mathbf{8}$}

\subsubsection{N-Benzyloxycarbonyl-L-glutamic Acid (16)}

$N$-Benzyloxycarbonyl-L-glutamic acid was prepared according to literature [21]. After recrystallization from ethyl acetate/hexanes (1:6), a white solid was obtained.

TLC $R_{\mathrm{F}}=0.48\left(\mathrm{CHCl}_{3} / \mathrm{MeOH} / \mathrm{NH}_{3} 2: 2: 1\right)$;

$[\alpha]_{\mathrm{D}}^{20}=-9.0(\mathrm{c}=2, \mathrm{AcOH})$;

Mp. $118^{\circ} \mathrm{C}$;

${ }^{1} \mathrm{H}-\mathrm{NMR}$ (600 MHz, DMSO): 12.4 (2H, very broad s, both protons of -COOH); $7.57(1 \mathrm{H}, \mathrm{d}$, $J=8.1 \mathrm{~Hz}, \mathrm{NH}), 7.35$ and $7.29(5 \mathrm{H}, \mathrm{m}, \mathrm{Ph}), 5.03\left(2 \mathrm{H}, \mathrm{s}, \mathrm{CH}_{2}\right.$ of Cbz), 3.99 (1H, m, CH-NHCbz), 2.29 $\left(2 \mathrm{H}, \mathrm{m}\right.$, both $\mathrm{H}$ of $\left.\mathrm{CH}_{2} \beta\right), 1.96$ and $1.75\left(2 \mathrm{H}, 2 \mathrm{~m}\right.$, both $\mathrm{H}$ of $\left.\mathrm{CH}_{2} \alpha\right)$;

${ }^{13} \mathrm{C}-\mathrm{NMR}$ (150 MHz, DMSO): 173.77 (CO $\gamma$ ), 173.62 (CO $), 156.20$ (CO of NHCbz), 137.00, 128.4, 127.8, $127.7(\mathrm{Ph}), 65.47\left(\mathrm{CH}_{2}\right.$ of $\left.\mathrm{Cbz}\right), 53.08$ ( $\left.\mathrm{CH}-\mathrm{NHCbz}\right), 30.12\left(\mathrm{CH}_{2} \beta\right), 26.13\left(\mathrm{CH}_{2} \alpha\right)$;

HRMS calcd for $\mathrm{C}_{13} \mathrm{H}_{15} \mathrm{NO}_{6} \mathrm{Na} m / z=304.0797$, found $m / z=304.0799$.

\subsection{2. $N$-Benzyloxycarbonyl-L-glutamic Acid $\alpha$-Ethyl Ester (17)}

The dicyclohexylammonium (DCHA) salt of compound 16 was prepared according to literature [25].

TLC $R_{\mathrm{F}}=0.75\left(\mathrm{CHCl}_{3} / \mathrm{MeOH} / \mathrm{NH}_{3} 2: 2: 1\right)$; DCHA salt

Mp. $160{ }^{\circ} \mathrm{C}$ (lit. [25] $\left.159-160{ }^{\circ} \mathrm{C}\right)$;

$[\alpha]_{\mathrm{D}}^{20}=-12.2(\mathrm{c}=0.5, \mathrm{MeOH})\left(\right.$ lit. $\left.[25][\alpha]_{\mathrm{D}}^{23-25}=-11.7(\mathrm{c}=2, \mathrm{MeOH})\right)$;

${ }^{1} \mathrm{H}-\mathrm{NMR} \delta: 8.12(1 \mathrm{H}, \mathrm{d}, J=6.6 \mathrm{~Hz}, \mathrm{NH}), 7.44-7.25(5 \mathrm{H}, \mathrm{m}$, all protons of $\mathrm{Ph}$ ring), $5.02(2 \mathrm{H}, 2 \times \mathrm{d}$, $J=12.7 \mathrm{~Hz}, \underline{\mathrm{C}}_{2}$ of Cbz), 4.09 (2H, $\underline{\mathrm{C}}_{2}$ of $\left.-\mathrm{O}-\mathrm{CH}_{2} \mathrm{CH}_{3}\right), 4.01$ (1H, m, CH-NH), 2.73, 2.15, 1.92-1.80, $1.75,1.67,1.56,1.28-1.05$;

${ }^{13} \mathrm{C}-\mathrm{NMR} \delta: 174.69,172.37,156.05,137.03,128.32,127.78,127.66,65.35,60.32,53.91,51.94$, $32.08,31.17,26.64,25.41,24.35,14.06$.

$1 \mathrm{M} \mathrm{H}_{2} \mathrm{SO}_{4}$ aq $(100 \mathrm{~mL})$ was added to the suspension of DCHA salt of $\mathbf{1 6}$ (8.63 g, $\left.17.58 \mathrm{mmol}\right)$ in AcOEt $(200 \mathrm{~mL})$. After $10 \mathrm{~min}$ water $(100 \mathrm{~mL})$ was added to the reaction mixture, the organic layer was separated and the aqueous phase extracted with AcOEt $(2 \times 150 \mathrm{~mL})$. The organic layers were collected, washed with water $(2 \times 50 \mathrm{~mL})$, dried over anhydrous $\mathrm{MgSO}_{4}$ and concentrated under reduced pressure to afford $17(5.0 \mathrm{~g}, 92 \%)$.

$[\alpha]_{\mathrm{D}}^{20}=-20.7(\mathrm{c}=0.5, \mathrm{MeOH})$;

${ }^{1} \mathrm{H}-\mathrm{NMR} \delta: 7.76(1 \mathrm{H}, \mathrm{d}, J=7.7 \mathrm{~Hz}, \mathrm{NH}), 7.38-7.29(5 \mathrm{H}, \mathrm{m}$, all protons of $\mathrm{Ph}$ ring), $5.03(2 \mathrm{H}, 2 \times \mathrm{d}$, $J=12.5 \mathrm{~Hz}, \mathrm{C}_{2}$ of $\left.\mathrm{Cbz}\right), 4.08\left(2 \mathrm{H}, \mathrm{m}, \mathrm{C}_{2}\right.$ of $\left.-\mathrm{CH}_{2} \mathrm{CH}_{3}\right), 4.04(1 \mathrm{H}, \mathrm{m}, \mathrm{CH}-\mathrm{NH}), 2.28(2 \mathrm{H}, \mathrm{m}$, $\left.-\underline{\mathrm{CH}_{2}}-\mathrm{COOH}\right), 1.93(1 \mathrm{H}, \mathrm{m}), 1.76(1 \mathrm{H}, \mathrm{m}), 1.17\left(3 \mathrm{H}, \mathrm{t}, J=7.1 \mathrm{~Hz}, \mathrm{CH}_{3}\right)$;

${ }^{13} \mathrm{C}-\mathrm{NMR} \delta: 173.96,172.12,156.11,136.94,128.34,127.83,127.70,65.46,60.50,53.27,30.23$, 26.09, 14.03; 
HRMS calcd for $\mathrm{C}_{15} \mathrm{H}_{19} \mathrm{NO}_{6} \mathrm{Na} m / z=332.1110$, found $m / z=332.1114$.

\subsubsection{L-Glutamic Acid $\alpha$-ethyl Ester (11)}

The solution of $17(5.0 \mathrm{~g}, 16.2 \mathrm{mmol})$ in EtOH $(150 \mathrm{~mL})$ was hydrogenated in the presence $10 \%$ $\mathrm{Pd} / \mathrm{C}(0.4 \mathrm{~g})$ for $2.5 \mathrm{~h}$. After filtration through a Celite pad, the solution was evaporated and dropped into $\mathrm{Et}_{2} \mathrm{O}(50 \mathrm{~mL})$. After cooling in the refrigerator, the white precipitate was filtered, washed with $\mathrm{Et}_{2} \mathrm{O}$, and dried in vacuum at $30{ }^{\circ} \mathrm{C}$ to give $\mathbf{1 1}(2.6 \mathrm{~g}, 93 \%)$.

TLC: $R_{\mathrm{F}}=0.65\left(\mathrm{CHCl}_{3} / \mathrm{MeOH} / \mathrm{NH}_{3} 2: 2: 1\right)$;

$[\alpha]_{\mathrm{D}}^{20}=+27.0(\mathrm{c}=2,1 \mathrm{M} \mathrm{HCl})$;

Mp. $90{ }^{\circ} \mathrm{C}$;

${ }^{1} \mathrm{H}-\mathrm{NMR} \delta$ : $5.00\left(3 \mathrm{H}\right.$, very broad $\mathrm{s},-\mathrm{N}_{2}$ and $\left.-\mathrm{COO} \underline{\mathrm{H}}\right), 4.10\left(2 \mathrm{H}, \mathrm{m},-\underline{\mathrm{C}}_{2} \mathrm{CH}_{3}\right), 3.37(1 \mathrm{H}, \mathrm{m}$, $\left.-\underline{\mathrm{HNH}}_{2}\right), 2.29\left(2 \mathrm{H}, \mathrm{m}\right.$, both $\mathrm{H}$ of $\left.\mathrm{CH}_{2} \beta\right), 1.83$ and $1.64(2 \mathrm{H}, 2 \mathrm{~m}$, both $\mathrm{H}$ of $\mathrm{CH} 2 \alpha), 1.20(3 \mathrm{H}, \mathrm{t}$, $\left.J=7.0 \mathrm{~Hz},-\mathrm{CH}_{2} \mathrm{CH}_{3}\right)$;

${ }^{13} \mathrm{C}-\mathrm{NMR} \delta$ : $174.80(\mathrm{CO} \alpha), 174.26(\mathrm{CO} \gamma), 60.20\left(-\underline{\mathrm{CH}}_{2} \mathrm{CH}_{3}\right), 53.12(-\underline{\mathrm{CHNH}} 2), 30.84\left(\mathrm{CH}_{2} \beta\right), 29.18$ $\left(\mathrm{CH}_{2} \alpha\right), 14.07\left(-\mathrm{CH}_{2} \underline{\mathrm{CH}}_{3}\right)$;

${ }^{15} \mathrm{~N}-\mathrm{NMR} \delta$ : -351.5 ;

HRMS: calcd for $\mathrm{C}_{7} \mathrm{H}_{14} \mathrm{NO}_{4} \mathrm{~m} / z=176.0923$, found $m / z=176.0926$.

3.5.4. (2S)-2-[[4-[2-(2-Amino-4-oxo-4,7-dihydro-1H-pyrrolo[2,3- $d]$ pyrimidin-5yl)ethyl]benzoyl]amino]-pentanedioic Acid 1-Ethyl Ester (18)

NMM (1.99 mL, $18.11 \mathrm{mmol})$, followed by CDMT (1.94 g, $11.06 \mathrm{mmol})$ were added to the suspension of acid $2(3 \mathrm{~g}, 10.06 \mathrm{mmol})$ in DMF $(30 \mathrm{~mL})$ and the resulting solution was stirred at $R T$ for $2 \mathrm{~h}$. $\alpha$-ethyl L-glutamate $11(1.85 \mathrm{~g}, 10.56 \mathrm{mmol})$ was added to this solution and the resulting mixture was stirred for $24 \mathrm{~h}$. The reaction mixture was poured into water $(30 \mathrm{~mL})$ and extracted with $\mathrm{CH}_{2} \mathrm{Cl}_{2}(3 \times 30 \mathrm{~mL})$. The organic phases were collected, dried over anhydrous $\mathrm{MgSO}_{4}$ and concentrated to afford $18(2.83 \mathrm{~g}, 61 \%)$.

TLC: $R_{\mathrm{F}}=0.67$. $\left(\mathrm{CHCl}_{3} / \mathrm{MeOH}, 4: 6\right)$;

${ }^{1} \mathrm{H}-\mathrm{NMR} \delta$ : $11.1(1 \mathrm{H}$, broad s, probably N1-H), $10.57(1 \mathrm{H}, \mathrm{s}, \mathrm{N} 9-\mathrm{H}), 10.38(1 \mathrm{H}, \mathrm{s}, \mathrm{N} 17-\mathrm{H}), 7.80$ (2H, m, H14), 7.23(2H, m, H13), 6.49 (2H, s, NH 2 at $\mathrm{C} 2), 6.27(1 \mathrm{H}, \mathrm{s}, \mathrm{H} 8), 4.20(1 \mathrm{H}, \mathrm{m}, \mathrm{H} 18), 4.07$ $\left(2 \mathrm{H}, \mathrm{m},-\mathrm{C}_{2} \mathrm{CH}_{3}\right.$ at $\left.\mathrm{C} 22\right), 2.92$ (2H, m, H11), 2.82 (2H, m, H10), 2.19 (2H, m, H20), 1.95 (2H, m, $\mathrm{H} 19), 1.16\left(3 \mathrm{H}, \mathrm{t}, J=7.1 \mathrm{~Hz},-\mathrm{CH}_{2} \mathrm{CH}_{3}\right.$ at $\left.\mathrm{C} 22\right)$;

${ }^{13} \mathrm{C}-\mathrm{NMR} \delta: 176.78$ (CO, C21), 172.28 (CO, C22), 165.96 (C16), 159.70 (C6), 152.79 (C2), 151.52 (C4), 145.93 (C12), 131.16 (C15), 128.16 (C13), 127.30 (C14), 117.69 (C7), 113.09 (C8), 98.66 (C5), 60.09 (-O- $\left.\underline{C H}_{2} \mathrm{CH}_{3}\right), 54.12$ (C18), 36.16 (C11), 33.97 (C20), 28.00 (C10), 26.37 (C19), $14.15\left(-\mathrm{O}-\mathrm{CH}_{2} \underline{\mathrm{CH}_{3}}\right)$;

${ }^{15} \mathrm{~N}-\mathrm{NMR} \delta$ : $-309.9\left(\mathrm{NH}_{2}\right.$ at $\left.\mathrm{C} 2\right),-263.7$ (N17), -241.8 (N9); N1 and $\mathrm{N} 3$ not recorded in ${ }^{1} \mathrm{H}-{ }^{15} \mathrm{~N} g$-HMBC experiment;

HRMS calcd for $\mathrm{C}_{22} \mathrm{H}_{25} \mathrm{~N}_{5} \mathrm{O}_{6} \mathrm{Na} m / z=478.1703$, found $m / z=478.1694$. 
3.5.5. (2S)-2-[[(4S)-4-[[4-[2-Amino-4-oxo-4,7-dihydro-1H-pyrrolo[2,3-d]pyrimidin-5yl)ethyl]benzoyl]amino]-4-(ethoxycarbonyl)butanoyl]amino]pentanedioic Acid Diethyl Ester, $p$-TSA Salt (19a)

NMM (1.57 mL, $14.28 \mathrm{mmol})$ was added to the suspension of $\mathbf{1 8}(2.33 \mathrm{~g}, 5.12 \mathrm{mmol})$ in DMF $(20 \mathrm{~mL})$, followed by CDMT (1.08 g, $6.15 \mathrm{mmol})$, and the resulting solution was stirred at $R T$ for $3 \mathrm{~h}$. diethyl L-glutamate hydrochloride $4(1.34 \mathrm{~g}, 5.61 \mathrm{mmol})$ was added to this solution and the resulting mixture was stirred for $24 \mathrm{~h}$. Then water $(30 \mathrm{~mL})$ and $\mathrm{CH}_{2} \mathrm{Cl}_{2}(30 \mathrm{~mL})$ were added to the reaction mixture which was stirred for $15 \mathrm{~min}$. The organic layer was separated and the aqueous phase extracted with $\mathrm{CH}_{2} \mathrm{Cl}_{2}(2 \times 25 \mathrm{~mL})$. The organic layers were collected, washed with $1 \mathrm{M} \mathrm{NaHCO}_{3 a q}$ $(1 \times 35 \mathrm{~mL})$, and concentrated under reduced pressure to afford oil.

EtOH $(40 \mathrm{~mL})$, followed by the solution of $p$-TSA $\cdot \mathrm{H}_{2} \mathrm{O}$ in EtOH $(2.46 \mathrm{~g}$ in $40 \mathrm{~mL}$ EtOH$)$ were added to the oil and the resulting suspension was heated under reflux for $2 \mathrm{~h}$. Then the mixture was cooled to $R T$, the crystals were filtered, washed with $\mathrm{EtOH}(2 \times 15 \mathrm{~mL})$ and dried in vacuo at $40{ }^{\circ} \mathrm{C}$ for $24 \mathrm{~h}$ to provide $19 \mathrm{a}(1.05 \mathrm{~g}, 25 \%)$.

TLC: $R_{\mathrm{F}}=0.46\left(\mathrm{CHCl}_{3} / \mathrm{MeOH} 8: 2\right)$;

Mp. $232{ }^{\circ} \mathrm{C}$;

${ }^{1} \mathrm{H}-\mathrm{NMR} \delta: 11.39(1 \mathrm{H}, \mathrm{s}$, probably N1-H), $11.26(1 \mathrm{H}, \mathrm{s}, \mathrm{N} 9-\mathrm{H}), 8.67(1 \mathrm{H}, \mathrm{d}, J=7.3 \mathrm{~Hz}, \mathrm{~N}-\mathrm{H} 17)$, $8.27(1 \mathrm{H}, \mathrm{d}, J=7.6 \mathrm{~Hz}, \mathrm{~N}-\mathrm{H} 23), 7.80(2 \mathrm{H}, \mathrm{m}, \mathrm{H} 14), 7.53$ (2H, d, $J=8.0 \mathrm{~Hz}, p$-TSA), 7.30 (2H, m, H13), 7.15 (2H, d, $J=8.0 \mathrm{~Hz}, p$-TSA), $6.51(1 \mathrm{H}, \mathrm{s}, \mathrm{H} 8), 4.39$ (1H, m, H18), 4.24 (1H, m, H24), 4.11 $\left(2 \mathrm{H}, \mathrm{q}, J=7.0 \mathrm{~Hz}, \mathrm{CH}_{2}\right.$ of $-\mathrm{C}_{2} \mathrm{CH}_{3}$ at $\left.\mathrm{C} 22\right), 4.07\left(2 \mathrm{H}, \mathrm{q}, J=7.0 \mathrm{~Hz}, \mathrm{CH}_{2}\right.$ of $-\mathrm{C}_{2} \mathrm{CH}_{3}$ at $\left.\mathrm{C} 27\right), 4.04$ $\left(2 \mathrm{H}, \mathrm{q}, J=7.0 \mathrm{~Hz}, \mathrm{CH}_{2}\right.$ of $-\mathrm{C}_{2} \mathrm{CH}_{3}$ at $\left.\mathrm{C} 26\right), 2.97(2 \mathrm{H}, \mathrm{m}, \mathrm{H} 11), 2.90(2 \mathrm{H}, \mathrm{m}, \mathrm{H} 10), 2.36(2 \mathrm{H}, \mathrm{m}$, H26), 2.34-2.26 (5H, m, H20 and $\mathrm{CH}_{3}$ of $p$-TSA), 2.09 (1H, m, one of $\mathrm{H} 19$ protons), 1.96 (2H, m, one of the $\mathrm{H} 19$ protons and one of $\mathrm{H} 25$ protons), 1.81 (1H, $\mathrm{m}$, one of the $\mathrm{H} 25$ protons);

${ }^{13} \mathrm{C}-\mathrm{NMR}$ 8: 172.10 (CO, C27), 172.00 (CO, C22), $171.74(2 \times \mathrm{CO}, \mathrm{C} 28$ and $\mathrm{C} 21), 166.47$ (CO, C16), 157.45 (probably C6), 150.72 (probably C3), 145.70 (C12), 144.94 (CIV, p-TSA), 139.81 (probably C4), 138.12 (CIV, p-TSA), 131.32 (C15), 128.16 (C13), 128.16 (CH, p-TSA), 125.50 (CH, p-TSA), 118.92 (C7), 115.13 (C8), 99.00 (C5), $60.48\left(-\mathrm{O}-\underline{\mathrm{CH}}_{2} \mathrm{CH}_{3}\right.$ at $\left.\mathrm{C} 27\right), 60.44\left(-\mathrm{CH}_{2} \mathrm{CH}_{3}\right.$ at $\left.\mathrm{C} 22\right)$, $59.90\left(-\mathrm{CH}_{2} \mathrm{CH}_{3}\right.$ at $\left.\mathrm{C} 26\right), 52.38$ (C18), 51.22 (C24), 35.74 (C11), 31.38 (C20), 29.84 (C26), 27.25 (C10), 26.19 (C19), 26.03 (C25), 20.77 ( $\mathrm{CH}_{3}$ group of p-TSA), 14.09, 14.05 and 14.00 (carbons of $\mathrm{CH}_{3}$ of $-\mathrm{O}-\mathrm{CH}_{2} \mathrm{CH}_{3}$ groups);

${ }^{15} \mathrm{~N}-\mathrm{NMR} \delta$ : -266.8 (N23), -266.4 (N17), -242.1 (N9);

HRMS: calcd for $\mathrm{C}_{31} \mathrm{H}_{41} \mathrm{~N}_{6} \mathrm{O}_{9} \mathrm{~m} / z=641.2935$, found $m / z=641.2930$.

3.5.6. $(2 S)-2-[[(4 S)-4-[[4-[2-A m i n o-4-o x o-4,7-d i h y d r o-1 H$-pyrrolo[2,3- $d]$ pyrimidin-5yl)ethyl]benzoyl]amino]-4-carboxybutanoyl]amino]pentanedioic Acid (8)

Compound 19a (1.86 g, $2.28 \mathrm{mmol})$ was treated with $1 \mathrm{M} \mathrm{NaOH}_{\mathrm{aq}}(15 \mathrm{~mL})$, the mixture was stirred at $R T$. After $1 \mathrm{~h}$ the reaction mixture was adjusted to $\mathrm{pH} 3.0$ with $1 \mathrm{~N} \mathrm{HClaq}$, and the precipitate was formed. After $30 \mathrm{~min}$ the precipitate was filtered off, washed with water $(2 \times 10 \mathrm{~mL})$ and dried to give crude 8. The crude material $(1.60 \mathrm{~g})$ was purified by column chromatography $\left(\mathrm{SiO}_{2}\right.$, $\mathrm{CHCl}_{3}-\mathrm{MeOH}-\mathrm{H}_{2} \mathrm{O}-25 \% \mathrm{NH}_{3 \text { aq }}$ 40:40:5:2) to give fraction of $\mathbf{8}, 668 \mathrm{mg}$ (HPLC 98.6\%). The obtained 
material $(660 \mathrm{mg})$ was then dissolved in water $(10 \mathrm{~mL})$ and the solution was acidified to $\mathrm{pH}=3$ with $10 \% \mathrm{HCl}_{\mathrm{aq}}(\mathrm{ca} .2 .5 \mathrm{~mL}$ ), forming a precipitate. The mixture was stirred at $R T$ for $30 \mathrm{~min}$, then the precipitate was filtered off, washed with water $(3 \times 15 \mathrm{~mL})$ and dried to give 8 (in triacid form, $0.48 \mathrm{~g}$, $37.6 \%$ from 19a, HPLC 98.0\%). A second fraction of 8 (390 mg, HPLC 91.5\%) was obtained by chromatography and acidified as described above to give 8 in the triacid form $(0.27 \mathrm{~g}$, yield $21.4 \%$ from 19a, HPLC purity $97.6 \%$ ).

$[\alpha]_{\mathrm{D}}^{20}=-3.87(\mathrm{c}=1, \mathrm{DMSO})$;

Mp. $155^{\circ} \mathrm{C}$;

${ }^{1} \mathrm{H}-\mathrm{NMR} \delta: 12.40$ (ca. 3H, broad s, 3×COOH), $10.61(1 \mathrm{H}, \mathrm{s}, \mathrm{N} 9-\mathrm{H}), 10.18(1 \mathrm{H}, \mathrm{s}, \mathrm{N} 1-\mathrm{H}), 8.57(1 \mathrm{H}$, d, $J=7.6 \mathrm{~Hz}, \mathrm{~N} 17-\mathrm{H}), 8.13(1 \mathrm{H}, \mathrm{d}, J=7.8 \mathrm{~Hz}, \mathrm{~N} 23-\mathrm{H}), 7.80$ (2H, m, H14), 7.29 (2H, m, H13), 6.31 $(1 \mathrm{H}, \mathrm{s}, \mathrm{H} 8), 6.03\left(2 \mathrm{H}, \mathrm{s}, \mathrm{NH}_{2}\right.$ at $\left.\mathrm{C} 2\right), 4.35(1 \mathrm{H}, \mathrm{m}, \mathrm{H} 18), 4.21(1 \mathrm{H}, \mathrm{m}, \mathrm{C} 24), 2.98$ (2H, m, H11), 2.86 (2H, m, H10), 2.28 (2H, m, H20), 2.27 (2H, m, H26), 2.10 (1H, m, H19), 1.94 (2H, m, H19 and H25), 1.75 (H25);

${ }^{13} \mathrm{C}-\mathrm{NMR} \delta: 173.77$ (CO, C27), 173.54 (CO, C22), 173.39 (CO, C28), 171.75 (CO, C21), 166.43 (CO, C16), 159.30 (CO, C6), 152.22 (C2), 151.33 (probably C4), 146.12 (C12), 131.39 (C15), 128.15 (C13), 127.38 (C14), 117.64 (C7), 113.46 (C8), 98.75 (C5), 52.31 (C18), 51.19 (C24), 36.14 (C11), 31.76 (C20), 30.14 (C26), 28.02 (C10), 26.48 (C19), 26.39 (C25);

${ }^{15} \mathrm{~N}-\mathrm{NMR} \quad \delta:-311.2\left(\mathrm{C} 2-\mathrm{NH}_{2}\right),-265.6(\mathrm{~N} 17),-260.0(\mathrm{~N} 23),-241.4(\mathrm{~N} 9),-236.4$ (N1), $-208.0(\mathrm{~N} 3)$;

HRMS: calcd for $\mathrm{C}_{25} \mathrm{H}_{27} \mathrm{~N}_{6} \mathrm{O}_{9} m / z=555.1840$, found $m / z=555.1851$.

FT-IR: [cm $\left.{ }^{-1}\right] 3312\left(\mathrm{~N}-\mathrm{H}_{v}, \mathrm{O}-\mathrm{H}_{v}\right) ; 2926\left(\mathrm{C}-\mathrm{H}_{v}\right) ; 1702\left(\mathrm{C}=\mathrm{O}_{v}\right) ; 1647\left(\mathrm{C}=\mathrm{O}_{v}, \mathrm{C}=\mathrm{N}_{v}\right) ; 1504\left(\mathrm{C}=\mathrm{C}_{v}\right)$; $1541\left(\mathrm{~N}-\mathrm{H}_{\delta}, \mathrm{C}=\mathrm{N}_{v}\right) ; 1448,1407\left(\mathrm{C}-\mathrm{H}_{\delta}\right) ; 1330\left(\mathrm{C}-\mathrm{N}_{v}\right) ; 1223\left(\mathrm{C}-\mathrm{O}_{v}, \mathrm{C}-\mathrm{N}_{v}\right) ; 666\left(\mathrm{C}-\mathrm{H}_{\gamma}, \mathrm{N}-\mathrm{H}_{\gamma}\right)$.

Adjusting the reaction mixture's $\mathrm{pH}$ to 8 enabled the isolation of the trisodium salt $\mathbf{8 a}$ (details are given in the Supplementary Part).

\subsection{Synthesis of Impurity (S,S)-9 and Diastereoisomer (S,R)-9}

3.6.1. (2S)-2-[(2S)-2-Carboxybenzylamino-4-(ethoxycarbonyl)butanoyl]aminopentanedioic Acid Diethyl Ester $((\boldsymbol{S}, \boldsymbol{S})-\mathbf{2 2})$

DIPEA (3.0 mL, $17.2 \mathrm{mmol})$ was added to the suspension of $N$-Cbz protected $(\boldsymbol{S})-\mathbf{1 2}(1.4 \mathrm{~g}, 4.53 \mathrm{mmol}$ prepared according to the literature procedure [26]) in DMF $(15 \mathrm{~mL})$, followed by HATU (2.07 $\mathrm{g}$, $5.43 \mathrm{mmol})$. The resulting solution was stirred at $R T$ for $1 \mathrm{~h}$. Then diethyl L-glutamate hydrochloride 4 $(1.63 \mathrm{~g}, 6.79 \mathrm{mmol})$ was added to the solution and the resulting mixture was stirred for $24 \mathrm{~h}$. The reaction mixture was diluted with water $(70 \mathrm{~mL})$ and extracted with AcOEt $(3 \times 25 \mathrm{~mL})$. The combined organic layers were washed with $1 \mathrm{M} \mathrm{HClaq}(1 \times 25 \mathrm{~mL}), 5 \% \mathrm{NaHCO}_{3}$ aq $(1 \times 25 \mathrm{~mL})$, sat. brine $(1 \times 25 \mathrm{~mL})$, dried over $\mathrm{Na}_{2} \mathrm{SO}_{4}$, and concentrated to give crude $(\boldsymbol{S}, \boldsymbol{S})$-22 as oil. The oil was crystallized from the AcOEt/hexanes mixture to obtain pure dipeptide $(\boldsymbol{S}, \boldsymbol{S})-\mathbf{2 2}$ as a solid (53.2\%).

TLC: $R_{\mathrm{F}}=0.52$ (hexanes/AcOEt $\left.1: 1\right)$;

$[\alpha]_{\mathrm{D}}^{20}=-20.70(\mathrm{c}=1.0 \mathrm{MeOH})$;

Mp. Phase trans.: peak endothermic. $1=84.3{ }^{\circ} \mathrm{C}$; peak exothermic. $=89.2{ }^{\circ} \mathrm{C}$; peak endothermic. $2=109.8^{\circ} \mathrm{C}$; 
${ }^{1} \mathrm{H}-\mathrm{NMR} \delta: 8.34(1 \mathrm{H}, \mathrm{d}, J=7.8 \mathrm{~Hz}, \mathrm{NH}), 7.46(1 \mathrm{H}, \mathrm{d}, J=7.8 \mathrm{~Hz}, \mathrm{Cbz}-\mathrm{NH}), 7.38-7.28$ (5H, Ph), $5.02\left(2 \mathrm{H}, \mathrm{dd}, J=12.5 \mathrm{~Hz}, \mathrm{CH}_{2}\right.$ of $\mathrm{Cbz}$ group), $4.26\left(1 \mathrm{H}, \mathrm{m}, \mathrm{CH}_{\alpha}\right), 4.10-4.02\left(7 \mathrm{H}, \mathrm{m}\right.$, all $\mathrm{CH}_{2}$ of ester $-\mathrm{CH}_{2} \mathrm{CH}_{3}$ groups and $\left.\mathrm{CH}_{\alpha}\right), 2.40-2.32\left(4 \mathrm{H}, \mathrm{m}\right.$, all $\mathrm{CH}_{\gamma}$ protons $), 2.00+1.84\left(2 \mathrm{H}, 2 \times \mathrm{m}\right.$, both $\mathrm{CH}_{\beta}$ protons), $1.91+1.78\left(2 \mathrm{H}, 2 \times \mathrm{m}\right.$, both $\mathrm{CH}_{\beta}$ protons $), 1.17\left(9 \mathrm{H}\right.$, three overlapping triplets, all $\mathrm{CH}_{3}$ of ester $-\mathrm{CH}_{2} \mathrm{CH}_{3}$ groups);

${ }^{13} \mathrm{C}-\mathrm{NMR} \delta$ : 172.3, 172.1, 171.4 (CO of ester groups), 171.6 (CO of amide group), 155.8 (CO of Cbz group), 137.0 ( $\mathrm{C}_{\mathrm{IV}}$ of $\left.\mathrm{Ph}\right), 128.3,127.8$ and $127.6(\mathrm{Ph}), 65.4\left(\mathrm{CH}_{2}\right.$ of $\mathrm{Cbz}$ group), 60.6, 59.9 and $59.8\left(\mathrm{CH}_{2}\right.$ carbons of ester $-\mathrm{CH}_{2} \mathrm{CH}_{3}$ groups), $53.6\left(\mathrm{CH}_{\alpha}\right), 51.2\left(\mathrm{CH}_{\alpha}\right) 30.0,29.8$ (both $\mathrm{CH}_{\gamma}$ carbons), 27.2, 25.8 (both $\mathrm{CH}_{\beta}$ carbons), 14.0 and 13.9 (all $\mathrm{CH}_{3}$ carbons of ester $-\mathrm{CH}_{2} \mathrm{CH}_{3}$ groups).

HRMS calcd for $[\mathrm{M}+\mathrm{H}]^{+} \mathrm{C}_{24} \mathrm{H}_{35} \mathrm{~N}_{2} \mathrm{O}_{9} m / z=495.2343$, found $m / z=495.2344$.

3.6.2. (2S)-2-[(2R)-2-Carboxybenzylamino-4-(ethoxycarbonyl)butanoyl]aminopentanedioic Acid Diethyl Ester $((\boldsymbol{S}, \boldsymbol{R})-\mathbf{2 2})$

(R)-12 prepared according to the literature procedure [26] was coupled with $\mathbf{4}$ analogically to the preparation of $(\boldsymbol{S}, \boldsymbol{S})$-22 to give triester $(\boldsymbol{S}, \boldsymbol{R})-\mathbf{2 2}$.

TLC: $R_{\mathrm{F}}=0.44$ (hexanes/AcOEt $\left.3: 2\right)$;

$[\alpha]_{\mathrm{D}}^{20}=-5.12(\mathrm{c}=1.0 \mathrm{MeOH})$;

Mp. $90.3^{\circ} \mathrm{C}$;

${ }^{1} \mathrm{H}-\mathrm{NMR} \delta: 8.34(1 \mathrm{H}, \mathrm{d}, J=7.8 \mathrm{~Hz}, \mathrm{NH}), 7.40(1 \mathrm{H}, \mathrm{d}, J=7.8 \mathrm{~Hz}, \mathrm{Cbz}-\mathrm{NH}), 7.38-7.28(5 \mathrm{H}, \mathrm{Ph})$, $5.02\left(2 \mathrm{H}, \mathrm{m}, \mathrm{CH}_{2}\right.$ of $\mathrm{Cbz}$ group), $4.21\left(1 \mathrm{H}, \mathrm{m}, \mathrm{CH}_{\alpha}\right), 4.10-4.02\left(7 \mathrm{H}, \mathrm{m}\right.$, all $\mathrm{CH}_{2}$ of ester $-\mathrm{CH}_{2} \mathrm{CH}_{3}$ groups and $\left.\mathrm{CH}_{\alpha}\right), 2.36-2.28\left(4 \mathrm{H}, \mathrm{m}\right.$, all $\mathrm{CH}_{\gamma}$ protons $), 2.00+1.84\left(2 \mathrm{H}, 2 \times \mathrm{m}\right.$, both $\mathrm{CH}_{\beta}$ protons $)$, $1.88+1.78\left(2 \mathrm{H}, 2 \times \mathrm{m}\right.$, both $\mathrm{CH}_{\beta}$ protons $), 1.17\left(9 \mathrm{H}\right.$, three overlapping triplets, all $\mathrm{CH}_{3}$ of ester $-\mathrm{CH}_{2} \mathrm{CH}_{3}$ groups);

${ }^{13} \mathrm{C}-\mathrm{NMR} \delta$ : 172.4, 172.3, 171.7 (CO of ester groups), 171.5 (CO of amide group), 156.0 (CO of Cbz group), 137.0 ( $\mathrm{CIV}$ of $\mathrm{Ph}), 128.4,127.9$ and $127.7(\mathrm{Ph}), 65.6\left(\mathrm{CH}_{2}\right.$ of $\mathrm{Cbz}$ group), 60.8, 60.1 and $60.0\left(\mathrm{CH}_{2}\right.$ carbons of ester $-\mathrm{CH}_{2} \mathrm{CH}_{3}$ groups), $53.9\left(\mathrm{CH}_{\alpha}\right), 51.3\left(\mathrm{CH}_{\alpha}\right) 30.1,29.8$ (both $\mathrm{CH}_{\gamma}$ carbons), 27.4, 26.0 (both $\mathrm{CH}_{\beta}$ carbons), 14.1 and 14.0 (all $\mathrm{CH}_{3}$ carbons of ester $-\mathrm{CH}_{2} \mathrm{CH}_{3}$ groups).

HRMS calcd for $[\mathrm{M}+\mathrm{Na}]^{+} \mathrm{C}_{24} \mathrm{H}_{34} \mathrm{~N}_{2} \mathrm{O}_{9} \mathrm{Na} m / z=517.2162$, found $m / z=517.2154$.

3.6.3. (2S)-2-[[(2S)-2-[[4-[2-Amino-4-oxo-4,7-dihydro-1H-pyrrolo[2,3- $d]$ pyrimidin-5yl)ethyl]benzoyl]amino]-4-(ethoxycarbonyl)butanoyl]amino]pentanedioic Acid Diethyl Ester $((\boldsymbol{S}, \boldsymbol{S})-\mathbf{2 1})$

The solution of triester $(\boldsymbol{S}, \boldsymbol{S})-\mathbf{2 2}(800 \mathrm{mg}, 1.62 \mathrm{mmol})$ in EtOH $(20 \mathrm{~mL})$ was hydrogenated in the presence of $10 \% \mathrm{Pd} / \mathrm{C}(0.4 \mathrm{~g})$ for $2.5 \mathrm{~h}$. After filtrating through a Celite pad, the solution was evaporated to obtain amino-triester as oil $(574 \mathrm{mg})$.

Acid 2 (296 mg, $0.99 \mathrm{mmol})$ was dissolved in DMF (10 mL), then DIPEA (0.52 mL, $2.97 \mathrm{mmol})$ was added followed by HATU (498 $\mathrm{mg}, 1.29 \mathrm{mmol}$ ) and the resulting solution was stirred at $R T$ for $30 \mathrm{~min}$. Then the solution of the previously obtained amino-triester $(500 \mathrm{mg}, 1.39 \mathrm{mmol})$ in $10 \mathrm{~mL}$ DMF was added and the resulting mixture was stirred overnight.

The reaction mixture was diluted with water $(25 \mathrm{~mL})$ and extracted with AcOEt $(3 \times 25 \mathrm{~mL})$. The combined organic layers were washed with $5 \% \mathrm{NaHCO}_{3}$ aq $(1 \times 25 \mathrm{~mL})$, dried over anhydrous $\mathrm{Na}_{2} \mathrm{SO}_{4}$ 
and concentrated to give crude $(\boldsymbol{S}, \boldsymbol{S})$-21 as oil. The oil was crystallized from the AcOEt/MTBE mixture to obtain pure dipeptide $(\boldsymbol{S}, \boldsymbol{S})$-21 as a solid (596 mg, 65\% from $(\boldsymbol{S}, \boldsymbol{S})-\mathbf{2 2})$.

TLC: $R_{\mathrm{F}}=0.35\left(\mathrm{CH}_{2} \mathrm{Cl}_{2} / \mathrm{MeOH} 10: 0.8\right)$;

$[\alpha]_{\mathrm{D}}^{20}=-1.20(\mathrm{c}=1.0 \mathrm{MeOH})$;

Mp. $149.1{ }^{\circ} \mathrm{C}$;

${ }^{1} \mathrm{H}-\mathrm{NMR} \delta: 10.60(1 \mathrm{H}, \mathrm{d}, J=2.0 \mathrm{~Hz}, \mathrm{H} 9) ; 10.15(1 \mathrm{H}, \mathrm{s}, \mathrm{H} 1) ; 8.37(1 \mathrm{H}, \mathrm{d}, J=7.5 \mathrm{~Hz}, \mathrm{H} 23) ; 8.35$ $(1 \mathrm{H}, \mathrm{d}, J=7.8 \mathrm{~Hz}, \mathrm{H} 17) ; 7.79$ and $7.28\left(2 \times 2 \mathrm{H}, \mathrm{AA}^{\prime} \mathrm{BB}^{\prime}, \mathrm{H} 13\right.$ and H14); $6.30(1 \mathrm{H}, \mathrm{m}, \mathrm{H} 8) ; 6.00(2 \mathrm{H}, \mathrm{s}$,

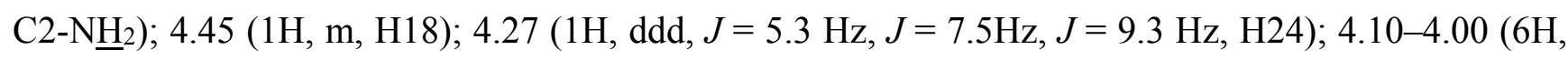
ov, m, $\left.3 \times-\underline{\mathrm{CH}}_{2} \mathrm{CH}_{3}\right) ; 2.97(2 \mathrm{H}, \mathrm{m}, \mathrm{H} 11) ; 2.85$ (2H, m, H10); $2.41(2 \mathrm{H}, \mathrm{m}, \mathrm{ov}, \mathrm{H} 20) ; 2.39$ (2H, m, ov, H26); 2.05 (1H, m, ov, H19); 2.01 (1H, m, ov, H25); 1.95 (1H, m, ov, H19); 1.86 (1H, m, H25); $1.18-1.14\left(9 \mathrm{H}, 3 \mathrm{t}\right.$, ov, $\left.J=7.1 \mathrm{~Hz}, 3 \times-\mathrm{CH}_{2} \underline{\mathrm{CH}_{3}}\right)$;

${ }^{13} \mathrm{C}-\mathrm{NMR} \delta$ : 172.4 (C21); 172.2 (C27); 171.6 (C22); 171.5 (C28); 166.4 (C16); 159.3 (C6); 152.2 (C2); 151.3 (C4); 146.1 (C12); 131.4 (C15); 128.1 (C13); 127.4 (C14); 117.6 (C7); 113.4 (C8); 98.8

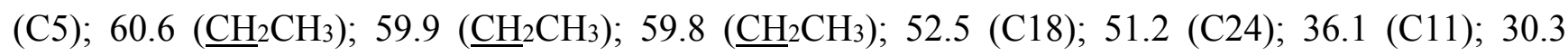
(C20); 29.8 (C26); 28.0 (C10); 26.9 (C19); 25.8 (C25); 14.04 (2C, $\left.-\mathrm{CH}_{2} \underline{\mathrm{CH}}_{3}\right) ; 13.9\left(-\mathrm{CH}_{2} \underline{\mathrm{CH}_{3}}\right)$;

${ }^{15} \mathrm{~N}-\mathrm{NMR} \delta$ : -208.0 (N3); -236.3 (N1); -241.4 (N9); -263.7 (N23); -265.9 (N17); -311.2 (C2-NH2); HRMS calcd for $[\mathrm{M}+\mathrm{H}]^{+} \mathrm{C}_{31} \mathrm{H}_{41} \mathrm{~N}_{6} \mathrm{O}_{9} \mathrm{~m} / z=641.2935$, found $m / z=641.2930$.

3.6.4. (2S)-2-[[(2R)-2-[[4-[2-Amino-4-oxo-4,7-dihydro-1H-pyrrolo[2,3- $d]$ pyrimidin-5yl)ethyl]benzoyl]amino]-4-(ethoxycarbonyl)butanoyl]amino]pentanedioic Acid Diethyl Ester ((S,R)-21)

Triester $(\boldsymbol{S}, \boldsymbol{R})$-21 was obtained in a similar manner as $(\boldsymbol{S}, \boldsymbol{S})-\mathbf{2 1}$ starting from triester $(\boldsymbol{S}, \boldsymbol{R})-\mathbf{2 2}$.

Recrystallization from TBME gave $(\boldsymbol{S}, \boldsymbol{R})-\mathbf{2 1}$ as a white solid (yield $88.3 \%$ ). This material can be additionally purified by chromatography $\left(\mathrm{SiO}_{2}, \mathrm{CH}_{2} \mathrm{Cl}_{2}-\mathrm{MeOH}, 99: 1 \rightarrow 93: 7, v / v\right)$.

TLC: $R_{\mathrm{F}}=0.70\left(\mathrm{CH}_{2} \mathrm{Cl}_{2} / \mathrm{MeOH} 10: 1.4\right)$;

$[\alpha]_{\mathrm{D}}^{20}=-9.56(\mathrm{c}=1.0 \mathrm{MeOH})$;

${ }^{1} \mathrm{H}-\mathrm{NMR} \delta$ : $10.60(1 \mathrm{H}, \mathrm{d}, J=2.0 \mathrm{~Hz}, \mathrm{H} 9) ; 10.14(1 \mathrm{H}, \mathrm{s}, \mathrm{H} 1) ; 8.35(1 \mathrm{H}, \mathrm{d}, J=7.8 \mathrm{~Hz}, \mathrm{H} 23) ; 8.32$ $(1 \mathrm{H}, \mathrm{d}, J=7.9 \mathrm{~Hz}, \mathrm{H} 17) ; 7.79$ and $7.28\left(2 \times 2 \mathrm{H}, \mathrm{AA}^{\prime} \mathrm{BB}^{\prime}, \mathrm{H} 13\right.$ and H14); $6.3(1 \mathrm{H}, \mathrm{m}, \mathrm{H} 8) ; 6(2 \mathrm{H}, \mathrm{s}$, $\mathrm{H} 2) ; 4.48$ (1H, m, H18); 4.24 (1H, ddd, $J=5.3 \mathrm{~Hz}, J=7.8 \mathrm{~Hz}, J=9.3 \mathrm{~Hz}, \mathrm{H} 24) ; 4.10-4.00$ (6H, $3 \times \mathrm{m}$, ov, $\left.3 \times-\underline{\mathrm{CH}}_{2} \mathrm{CH}_{3}\right) ; 2.97(2 \mathrm{H}, \mathrm{m}, \mathrm{H} 11) ; 2.85(2 \mathrm{H}, \mathrm{m}, \mathrm{H} 10) ; 2.38(2 \mathrm{H}, \mathrm{m}, \mathrm{ov}, \mathrm{H} 20) ; 2.34$ (2H, m, ov, H26); 2.02 (1H, m, ov, H19); 2 (1H, m, ov, H25); $1.96(1 \mathrm{H}, \mathrm{m}$, ov, H19); 1.84 (1H, m, H25); $1.18-1.14\left(9 \mathrm{H}, 3 \times \mathrm{t}\right.$, ov, $\left.J=7.1 \mathrm{~Hz}, 3 \times-\mathrm{CH}_{2} \underline{\mathrm{CH}}_{3}\right)$;

${ }^{13} \mathrm{C}-\mathrm{NMR} \delta$ : 172.4 (C21); 172.2 (C27); 171.7 (C22); 171.5 (C28); 166.4 (C16); 159.4 (C6); 152.2 (C2); 151.4 (C4); 146.2 (C12); 131.4 (C15); 128.1 (C13); 127.5 (C14); 117.7 (C7); 113.5 (C8); 98.8 (C5); $60.6\left(-\underline{\mathrm{CH}}_{2} \mathrm{CH}_{3}\right) ; 59.9\left(2 \mathrm{C},-\underline{\mathrm{CH}}_{2} \mathrm{CH}_{3}\right) ; 52.7$ (C18); 51.2 (C24); 36.2 (C11); 30.4 (C20); 29.8 (C26); 28.0 (C10); 27.0 (C19); 25.9 (C25); $14.0\left(2 \mathrm{C},-\mathrm{CH}_{2} \underline{\mathrm{CH}}_{3}\right) ; 13.9\left(-\mathrm{CH}_{2} \underline{\mathrm{CH}_{3}}\right)$;

${ }^{15} \mathrm{~N}-\mathrm{NMR} \delta$ : $-208.0(\mathrm{~N} 3),-236.3(\mathrm{~N} 1) ;-241.4(\mathrm{~N} 9) ;-264.8(\mathrm{~N} 23) ;-266.0(\mathrm{~N} 17) ;-311.1\left(\mathrm{C}_{2}-\mathrm{NH}_{2}\right)$; HRMS calcd for $[\mathrm{M}+\mathrm{Na}]^{+} \mathrm{C}_{31} \mathrm{H}_{40} \mathrm{~N}_{6} \mathrm{O}_{9} \mathrm{Na} m / z=663.2754$, found $m / z=663.2734$. 
3.6.5. (2S)-2-[[(2S)-2-[[4-[2-Amino-4-oxo-4,7-dihydro-1H-pyrrolo[2,3-d]pyrimidin-5yl)ethyl]benzoyl]amino]-4-carboxybutanoyl]amino]pentanedioic Acid $((\boldsymbol{S}, \boldsymbol{S})-\mathbf{9})$

Triester $(\boldsymbol{S}, \boldsymbol{S})-21(100 \mathrm{mg}, 0.156 \mathrm{mmol})$ was treated with $1 \mathrm{M} \mathrm{NaOH}_{\mathrm{aq}}(6 \mathrm{~mL})$, the mixture was stirred at $R T$. After $30 \mathrm{~min}$ the reaction was completed (TLC control) and the mixture was acidified with $1 \mathrm{M} \mathrm{HCl}_{\mathrm{aq}}$ to $\mathrm{pH} \approx 3$. The formed precipitate was filtered off, washed with water and dried (vacuum drier, $38{ }^{\circ} \mathrm{C}$, overnight) to obtain $(S, S)-9(58 \mathrm{mg}, 66.8 \%)$.

TLC: $R_{\mathrm{F}}=0.37\left(2 \times \mathrm{CHCl}_{3}-\mathrm{MeOH} 1: 2\right) ; \mathrm{R}_{\mathrm{F}}=0.50\left(\mathrm{CHCl}_{3}-\mathrm{MeOH}-\mathrm{H}_{2} \mathrm{O}-25 \% \mathrm{NH}_{3 \mathrm{aq}} 40: 40: 10: 2\right)$

$[\alpha]_{\mathrm{D}}^{20}=+18.9(\mathrm{c}=1, \mathrm{DMSO})$;

Mp. $171.5^{\circ} \mathrm{C}$;

${ }^{1} \mathrm{H}-\mathrm{NMR} \delta: 10.60(1 \mathrm{H}, \mathrm{s}, \mathrm{H} 9) ; 10.17(1 \mathrm{H}, \mathrm{s}, \mathrm{H} 1) ; 8.34(1 \mathrm{H}, \mathrm{d}, J=7.8 \mathrm{~Hz}, \mathrm{H} 17) ; 8.21(1 \mathrm{H}, \mathrm{d}$, $J=7.8 \mathrm{~Hz}, \mathrm{H} 23) ; 7.78$ (2H, BB', H14); 7.28 (2H, AA', H13); 6.31 (1H, m, H8); 6.01 (2H, s, C2-NH2); 4.46 (1H, m, H18); 4.22 (1H, m, H24); 2.97 (2H, m, H11); 2.85 (2H, m, H10); 2.34 (2H, m, H20); 2.30 (2H, m, H26); 2.03 (1H, ov, m, H19); 1.99 (1H, ov, m, H25); 1.92 (1H, m, H19); 1.81 (1H, m, H25);

${ }^{13} \mathrm{C}-\mathrm{NMR} \delta$ : 174.3 (C21); 173.9 (C27); 173.3 (C28); 171.7 (C22); 166.6 (C16); 159.5 (C6); 152.3 (C2); 151.4 (C4); 146.2 (C12); 131.5 (C15); 128.2 (C13); 127.5 (C14); 117.5 (C7); 113.6 (C8); 98.8 (C5); 52.8 (C18); 51.3 (C24); 36.2 (C11); 30.5 (C20); 30.1 (C26); 28.1 (C10); 27.1 (C19); 27.1 (C19); $26.3(\mathrm{C} 25) ; 26.3(\mathrm{C} 25)$;

${ }^{15} \mathrm{~N}-\mathrm{NMR} \delta$ : -208 (N3); -236.3 (N1); -241.4 (N9); -263.2 (N23); -265.5 (N17); -311.1 (C2-NH2);

HRMS calcd for $\mathrm{C}_{25} \mathrm{H}_{29} \mathrm{~N}_{6} \mathrm{O}_{9} m / z=557.1996$, found $m / z=557.1989$.

FT-IR: [cm $\left.{ }^{-1}\right] 3315\left(\mathrm{~N}-\mathrm{H}_{v}, \mathrm{O}-\mathrm{H}_{v}\right) ; 2927\left(\mathrm{C}-\mathrm{H}_{v}\right) ; 1702\left(\mathrm{C}=\mathrm{O}_{v}\right) ; 1636\left(\mathrm{C}=\mathrm{O} v, \mathrm{C}=\mathrm{N}_{v}\right) ; 1534\left(\mathrm{~N}-\mathrm{H}_{\delta}\right.$, $\left.\mathrm{C}=\mathrm{N}_{v}\right) ; 1504\left(\mathrm{C}=\mathrm{C}_{v}\right) ; 1405\left(\mathrm{C}-\mathrm{H}_{\delta}\right) ; 1221\left(\mathrm{C}-\mathrm{O}_{v}, \mathrm{C}-\mathrm{N}_{v}\right) ; 669\left(\mathrm{C}-\mathrm{H}_{\gamma}, \mathrm{N}-\mathrm{H}_{\gamma}\right)$.

3.6.6. (2S)-2-[[(2R)-2-[[4-[2-Amino-4-oxo-4,7-dihydro-1H-pyrrolo[2,3-d]pyrimidin-5yl)ethyl]benzoyl]amino]-4-carboxybutanoyl]amino]pentanedioic Acid $((\boldsymbol{S}, \boldsymbol{R})-\mathbf{9})$

Triester $(\boldsymbol{S}, \boldsymbol{R})$-21 was hydrolyzed in the same manner as $(\boldsymbol{S}, \boldsymbol{S})-\mathbf{2 1}$ ( yield of $(\boldsymbol{S}, \boldsymbol{R})-\mathbf{2 1}, \mathbf{4 7 . 8 \%})$.

TLC: $R_{\mathrm{F}}=0.37\left(2 \times \mathrm{CHCl}_{3}-\mathrm{MeOH} 1: 2\right) ; \mathrm{R}_{\mathrm{F}}=0.50\left(\mathrm{CHCl}_{3}-\mathrm{MeOH}-\mathrm{H}_{2} \mathrm{O}-25 \% \mathrm{NH}_{3 \mathrm{aq}} 40: 40: 10: 2\right)$

$[\alpha]_{\mathrm{D}}^{20}=-23.46(\mathrm{c}=0.8, \mathrm{DMSO})$;

Mp. $156.7^{\circ} \mathrm{C}$;

${ }^{1} \mathrm{H}-\mathrm{NMR} \delta: 10.60$ (s, C9); $10.15(1 \mathrm{H}, \mathrm{s}, \mathrm{C} 1) ; 8.30(1 \mathrm{H}, \mathrm{d}, J=8.1 \mathrm{~Hz}, \mathrm{C} 17) ; 8.20(1 \mathrm{H}, \mathrm{d}, J=7.9 \mathrm{~Hz}$, C24); 7.79 (2H, BB', C14); 7.28 (2H, AA', C13); 6.32 (m, C8); 6.01 (2H, s, C2-NH2); 4.50 (1H, m, C18); $4.23(1 \mathrm{H}, \mathrm{m}, \mathrm{C} 25) ; 2.98(2 \mathrm{H}, \mathrm{m}, \mathrm{C} 11) ; 2.86(2 \mathrm{H}, \mathrm{m}, \mathrm{C} 10) ; 2.32(2 \mathrm{H}, \mathrm{m}, \mathrm{C} 21) ; 2.25(2 \mathrm{H}, \mathrm{m}$, C28); 2.01 (1H, m, ov, C20); 1.99 (1H, m, ov, C27); 1.94 (1H, m, ov, C19); 1.79 (1H, m, C26);

${ }^{13} \mathrm{C}-\mathrm{NMR} \delta$ : 174.1 (C22); 173.7 (C29); 173.1 (C30); 171.6 (C23); 166.4 (C16); 159.3 (C6); 152.2 (C2); 151.3 (C4); 146.1 (C12); 131.5 (C15); 128.1 (C13); 127.5 (C14); 117.7 (C7); 113.4 (C8); 98.7 (C5); 52.8 (C18); 51.1 (C25); 36.1 (C11); 30.5 (C21); 29.9 (C28); 28 (C10); 27.2 (C19); 27.2 (C20); 26.4 (C26); 26.4 (C27);

HRMS calcd for $\mathrm{C}_{25} \mathrm{H}_{29} \mathrm{~N}_{6} \mathrm{O}_{9} \mathrm{~m} / z=557.1996$, found $m / z=557.1989$. 
3.7. Synthesis of (2S,2'S)-2,2'-[[2,2'-Diamino-4,4',6-trioxo-1,4,4',6, 7,7'-hexahydro-1'H,5H-5, 6'bipyrrolo[2,3-d]pyrimidine-5,5'-diyl]bis(ethylenebenzene-4,1-diylcarbonylimino)]dipentanedioic Acid (Impurity 10)

Pemetrexed disodium heptahydrate (1a, $2.0 \mathrm{~g})$ was dissolved in $0.1 \mathrm{M} \mathrm{NaOH}_{\mathrm{aq}}(400 \mathrm{~mL})$ and heated under reflux for 3 days (TLC control). Then the mixture was cooled and evaporated under reduced pressure to get crude diastereoisomeric mixture $\mathbf{1 0}$ as brown oil.

The obtained mixture was purified by chromatography $\left(\mathrm{SiO}_{2}\right.$, EtOH-MeOH-AcOEt- $4 \% \mathrm{NH}_{3}$ aq, 40:30:10:12, v/v). The respective fractions were collected and concentrated. The residue was dissolved in water $(10 \mathrm{~mL})$ and the $\mathrm{pH}$ was adjusted to $2-3$ with $1 \mathrm{M} \mathrm{HClaq}$. The suspension was filtered, then the solid was washed with $\mathrm{H}_{2} \mathrm{O}(2 \times 2 \mathrm{~mL})$ and dried at $40{ }^{\circ} \mathrm{C}$ to obtain $10(407 \mathrm{mg}, 10 \%)$.

TLC: $R_{\mathrm{F}}=0.59\left(\mathrm{EtOH} / \mathrm{MeOH} / \mathrm{AcOEt} / 4 \% \mathrm{NH}_{3}\right.$ aq $\left.40: 30: 10: 12 v / v\right)$

HPLC purity $84.3 \%$

Mp. $230{ }^{\circ} \mathrm{C}$

HRMS: calcd for $\mathrm{C}_{40} \mathrm{H}_{39} \mathrm{~N}_{10} \mathrm{O}_{13} \mathrm{~m} / z=867.2698$, found $\mathrm{m} / \mathrm{z}=867.2709$

${ }^{1} \mathrm{H}-\mathrm{NMR} \delta$ : 12.39 (3H, ov, total for 21, 21', 22 and 22' $\left.-\mathrm{CO}_{2} \mathrm{H}\right), 10.87\left(1 \mathrm{H}, \mathrm{s}, \mathrm{N} 9^{\prime}-\mathrm{H}\right), 10.74(1 \mathrm{H}, \mathrm{s}$, N9-H), $10.60(1 \mathrm{H}$, bs, probably N1'-H), $10.09(1 \mathrm{H}, \mathrm{s}, \mathrm{N} 1-\mathrm{H}), 8.52(2 \mathrm{H}, 2 \times \mathrm{d}$, ov, N17-H and N17'-H), $7.80\left(4 \mathrm{H}, \mathrm{m}, \mathrm{H} 14\right.$ and H14'), $7.30\left(2 \mathrm{H}, \mathrm{d}, J=8.0 \mathrm{~Hz}, \mathrm{H} 13^{\prime}\right), 7.26(2 \mathrm{H}, \mathrm{d}, J=8.0 \mathrm{~Hz}, \mathrm{H} 13), 6.90$ (2H, bs, probably $\mathrm{NH}_{2}$ at $\left.\mathrm{C}^{\prime}\right), 6.02\left(2 \mathrm{H}, \mathrm{NH}_{2}\right.$ at $\left.\mathrm{C} 2\right), 4.41\left(2 \mathrm{H}, \mathrm{m}, \mathrm{H} 18\right.$ and $\left.\mathrm{H} 18^{\prime}\right), 2.72-2.54(6 \mathrm{H}, \mathrm{H} 11$, $\mathrm{H} 10$ and $\left.\mathrm{H} 10^{\prime}\right), 2.45$ (2H, H11'), 2.40-2.32 (4H, H20 and H20'), 2.10 and 1.97 (4H, H19 and H19');

${ }^{13} \mathrm{C}-\mathrm{NMR} \delta$ : 179.59 (C8'), 173.93, 173.90 (CO, C21 and C21'), 173.51 and 173.48 (CO, C22, C22'), 166.59 and 166.41 (CO, C16 and $\mathrm{C} 16^{\prime}$ ), 164.03 (probably C4'), 159.08 (C6), 157.76 (probably C6'), 157.63 (unknown, $\mathrm{C} 4$ or $\mathrm{C} 2$ '), 152.10 (unknown, $\mathrm{C} 4$ or $\mathrm{C} 2$ '), 150.29 (probably C2), 146.52 (C12), $145.00\left(\mathrm{C} 12^{\prime}\right), 131.49$ and 131.39 (C15 and C15'), 128.08 (C13'), $127.97(\mathrm{C} 13), 127.54$ and 127.42 (C14 and C14'), 114.22 (C7), 99.51 (C5), $92.71\left(\mathrm{C}^{\prime}\right), 51.91$ (C18 and C18'), 51.72 (C7'), 37.76 (C11), 34.18 (C10'), 30.44 (C20, C20'), 29.75 (C11'), 28.08 (C10), 25.98 (C19 and $\left.\mathrm{C} 19^{\prime}\right)$;

${ }^{15} \mathrm{~N}-\mathrm{NMR} \delta$ : $-311.0\left(\mathrm{NH}_{2}\right.$ at $\left.\mathrm{C} 2\right),-265.9\left(\mathrm{~N} 17\right.$ and $\left.\mathrm{N} 17^{\prime}\right),-238.9$ (N9), -236.2 (N1), -233.7 (N9'), all remaining ${ }^{15} \mathrm{~N}-\mathrm{NMR}$ signals not recorded in the ${ }^{1} \mathrm{H}-{ }^{15} \mathrm{~N} g$-HMBC experiment.

\section{Conclusions}

Herein we have developed and described the synthesis of the process-related impurities of pemetrexed disodium, the active ingredient of an anticancer therapeutic. The process related impurities $\mathbf{6 , 7}$ and 10 we synthesized by modified methods. For the impurities $\mathbf{8}$ and $\mathbf{9}$ we developed new synthetic methods. We found that during synthesis the impurity 9 a mixture of diastereoisomers can be formed. To avoid this process, we have developed an effective method of the synthesis of $\mathbf{9}$ where racemization does not occur. Two diastereoisomeric impurities 9 were obtained: $\boldsymbol{S}, \boldsymbol{S}-\mathbf{9}$ and, reported for the first time, $\boldsymbol{S}, \boldsymbol{R}-\mathbf{9}$.

The structure elucidation of all obtained impurities was discussed on the basis of two-dimensional NMR experiments and MS data and their physicochemical characterization was presented. We have developed HPLC methods for the determination of chemical and enantiomeric purity of pemetrexed disodium and its impurities. 
The determination of the impurity profile and elucidation of the structures of the main contaminants are of great importance when it comes to complying with the regulatory norms as well as assessing the quality of pemetrexed disodium as an API.

\section{Supplementary Material}

The IR characteristic of impurities 6, 7, 8 and 9, as well as experimental procedures and analytical data for the sodium salts of $\mathbf{7}$ and $\mathbf{8}$ and the mixture of diastereoisomers of $\mathbf{9}$ are collected in the supporting materials which can be accessed at: http://www.mdpi.com/1420-3049/20/06/10004/s1.

\section{Acknowledgments}

Support from the European and Regional Funds under the Innovative Economy Programme, grant number POIG.01.03.01-14-069/09-00, is gratefully acknowledged.

\section{Author Contributions}

Olga Michalak and Mariusz M. Gruza designed the experiments, analyzed the data, and wrote the paper. Piotr Cmoch performed the NMR experiment and analysis and wrote the paper. Anna Witkowska and Iwona Bujak designed and performed the analyses for all the compounds. All authors have read and approved the final manuscript.

\section{Conflicts of Interest}

The authors declare no conflict of interest.

\section{References and Notes}

1. Adjei, A.A. Pemetrexed (ALIMTA), A Novel Multitargeted Antineoplastic Agent. Clin. Cancer Res. 2004, 10, 4276s-4280s.

2. Walling, J. From methotrexate to pemetrexed and beyond. A review of the pharmacodynamic and clinical properties of antifolates. Investig. New Drugs 2006, 24, 37-77.

3. Hanauske, A.R.; Chen, V.; Paoletti, P.; Niyikiza, C. Pemetrexed Disodium: A Novel Antifolate Clinically Active against Multiple Solid Tumors. Oncologist 2001, 6, 363-373.

4. McGuire, J.J. Anticancer Antifolates: Current Status and Future Directions. Curr. Pharm. Des. 2003, 9, 2593-2613.

5. Taylor, E.C.; Kuhnt, D.; Shih, C.; Rinzel, S.M.; Grindey, G.B.; Barredo, J.; Jannatipour, M.; Moran, R.G. A dideazatetrahydrofolate analog lacking a chiral center at C-6: $N$-[4-[2-(2-amino3,4-dihydro-4-oxo-7H-pyrrolo[2,3- $d$ ]pyrimidin-5yl)ethyl[benzoyl]-L-glutamic acid is an inhibitor of thymidylate synthase. J. Med. Chem. 1992, 35, 4450-4454.

6. Guidance for Industry on Abbreviated New Drug Applications: Impurities in Drug Substances; Availability. Fed. Regist. 2009, 74, 34359-34360.

7. The International Conference on Harmonisation of Technical Requirements for Registration of Pharmaceuticals for Human Use. ICH Harmonised Tripartite Guideline: Impurities in New Drug Substances Q3A (R2); IGH: Geneva, Switzerland, 2006. 
8. Council of Europe. Pemetrexed disodium heptahydrate. In European Pharmacopoeia; EDQM, Council of Europe: Strasbourg, France, 2013; Volume 8, p. 2637.

9. International Conference on Harmonisation; revised guidance on Q3A impurities in new drug substances; availability. Notice. Fed. Regist. 2003, 68, 6924-6925.

10. Barnett, C.J.; Wilson, T.M.; Kobierski, M.E. A Practical Synthesis of Multitargeted Antifolate LY231514. Org. Process Res. Dev. 1999, 3, 184-188.

11. A manuscript describing the preparation of amorphic and hemipentahydrate pemetrexed disodium is under preparation.

12. Kjell, D.P.; Hallberg, D.W.; Kalbfleisch, J.M.; McCurry, C.K.; Semo, M.J.; Sheldon, E.M.; Spitler, J.T.; Wang, M. Determination of the Source of the $N$-Methyl Impurity in the Synthesis of Pemetrexed Disodium Heptahydrate. Org. Process Res. Dev. 2005, 9, 738-742.

13. Kadaboina, R.; Nariyam, S.M.; Murki, V.; Manda, A.; Vinjamuri, R.R.; Gunda, N. Processes for Preparing Pemetrexed. Patent WO2011019986, 13 October 2010.

14. Warner, A.; Piraner, I.; Weimer, H.; White, K. Development of a purity control strategy for pemetrexed disodium and validation of associated analytical methodology. J. Pharm. Biomed. Anal. 2015, 105, 46-54.

15. Abu-Shanab, F.A.; Redhouse, A.D.; Thompson, J.R.; Wakefield, B.J. Synthesis of 2,3,5,6-Tetrasubstituted Pyridines from Enamines Derived from $N, N$-Dimethylformamide Dimethyl Acetal. Synthesis 1995, 5, 557-560.

16. Nefkens, G.H.L.; Nivard, R.J.F. A new method for the synthesis of $\alpha$-esters of $N$-acylglutamic acids. Recl. Trav. Chim. Pays Bas 1964, 83, 199-207.

17. Klieger, E.; Gibian, H. Über Peptidsynthesen, X. Vereinfachte Darstellung und Reaktionen von Carbobenzoxy-L-glutaminsäure- $\alpha$-halbestern. Justus Liebigs Ann. Chem. 1962, 655, 195-210.

18. Garrett, C.E.; Jiang, X.; Prasad, K.; Repič, O. New observations on peptide bond formation using CDMT. Tetrahedron Lett. 2002, 43, 4161-4165.

19. Sewald, N. Efficient, Racemization-Free Peptide Coupling of $N$-Alkyl Amino Acids by Using Amino Acid Chlorides Generated In Situ-Total Syntheses of the Cyclopeptides Cyclosporin O and Omphalotin A. Angew. Chem. Int. Ed. 2002, 41, 4661-4663.

20. Bodanszky M.; Klausner Y.S.; Ondetti M.A. Peptide Synthesis, 2nd ed.; Wiley-Interscience: New York, NY, USA, 1976.

21. Hanby, W.E.; Waley, S.G.; Watson, J. 632. Synthetic polypeptides. Part II. Polyglutamic acid. J. Chem. Soc. 1950, 3239-3249.

22. Taylor, E.C.; Liu, B. A New and Efficient Synthesis of Pyrrolo[2,3- $d$ ]pyrimidine Anticancer Agents: Alimta (LY231514, MTA), Homo-Alimta, TNP-351, and Some Aryl 5-Substituted Pyrrolo[2,3-d]pyrimidines. J. Org. Chem. 2003, 68, 9938-9947.

23. Hu, D.X.; Grice, P.; Ley, S.V. Rotamers or Diastereomers? An Overlooked NMR Solution. J. Org. Chem. 2012, 77, 5198-5202.

24. Pirrung, M.C. Appendix 3: Recipes for TLC Stains. In The Synthetic Organic Chemist's Companion; John Wiley \& Sons, Inc.: Hoboken, NJ, US, 2007; pp. 171-172.

25. Gibian, H.; Schröder, E. Über Peptidsynthesen, III. Synthesen von Arginin-haltigen Peptiden. Justus Liebigs Ann. Chem. 1961, 642, 145-162. 
26. Feng, X.; Edstrom, E.D. A synthetic approach to diaryl ethers using the Robinson annulation. Tetrahedron Asymmetry 1999, 10, 99-105.

Sample Availability: Samples of the compounds $(\boldsymbol{S}, \boldsymbol{S})-\mathbf{2 1}$ and $(\boldsymbol{S}, \boldsymbol{R})-\mathbf{2 2}$ are available from the authors to individual enquiry.

(C) 2015 by the authors; licensee MDPI, Basel, Switzerland. This article is an open access article distributed under the terms and conditions of the Creative Commons Attribution license (http://creativecommons.org/licenses/by/4.0/). 